\title{
Republic of Tajikistan: First Assessment Under the 2008 Staff-Monitored Program
}

This paper on the First Assessment Under the 2008 Staff-Monitored Program for the Republic of Tajikistan was prepared by a staff team of the International Monetary Fund as background documentation for the periodic consultation with the member country. It is based on the information available at the time it was completed on December 10, 2008. The views expressed in this document are those of the staff team and do not necessarily reflect the views of the government of the Republic of Tajikistan or the Executive Board of the IMF.

The policy of publication of staff reports and other documents by the IMF allows for the deletion of market-sensitive information.

Copies of this report are available to the public from

International Monetary Fund $\bullet$ Publication Services

700 19th Street, N.W. • Washington, D.C. 20431

Telephone: (202) 623-7430 • Telefax: (202) 623-7201

E-mail: publications@imf.org • Internet: http://www.imf.org

Price: $\$ 18.00$ a copy

\section{International Monetary Fund \\ Washington, D.C.}



INTERNATIONAL MONETARY FUND

REPUBLIC OF TAJIKISTAN

First Assessment Under the 2008 Staff-Monitored Program

Prepared by the Middle East and Central Asia Department

(in consultation with other departments)

Approved by David Owen and Patricia Alonso-Gamo

December 10, 2008

Mission dates: October 27-November 5, 2008

Team: F. Alturki, C. Oner, A. Schimmelpfennig (head), S. Vtyurina (all MCD), V. Stepanyan (SPR), and L. Moers (resident representative). Mr. Owen (MCD) joined at the beginning of the mission. Mr. Zavkiev (OED) participated in key policy meetings.

Tajik officials: President Rakhmon, State Economic Advisor Davlatov, Minister of Finance Nadjmuddinov, and National Bank of Tajikistan (NBT) Chairman Rakhimzoda.

Fund relations: The last Article IV consultation was concluded on March 28, 2007. On March 5, 2008, the Executive Board met to discuss the misreporting episode under the last Poverty Reduction and Growth Facility (PRGF) arrangement. They supported the Managing Director's recommendation that Tajikistan repay early the three noncomplying disbursements (amounting to SDR 29.4 million) that were not discharged under MDRI relief; monthly payments of SDR 4.9 million were received in September, October, and November 2008, and the remaining three payments will be made through February 2009.

Staff-Monitored Program (SMP): A six-month SMP was negotiated in May 2008, covering the period June-December 2008. The authorities met most quantitative targets for end-September, and complied with all structural benchmarks at end-September. The on-site field work related to the special audit of the NBT has been completed, and the auditors are finalizing their report. Prospects for meeting end-December targets are favorable. In the attached letter, the authorities confirm their policy intentions for 2008 and outline their objectives for 2009.

Exchange rate regime: Classified as a conventional peg.

Outreach: The mission met with local representatives of the Asian Development Bank, the World Bank, EBRD, EU, UNDP, and briefed members of the diplomatic community. There were two press briefings during the mission. 


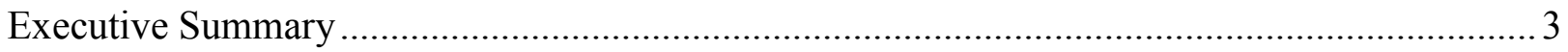

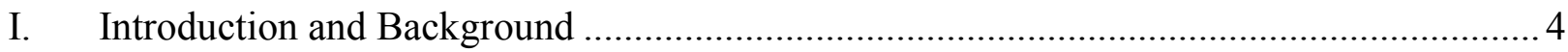

II. Recent Economic Developments and Outlook ................................................... 4

III. Policy Discussions ............................................................................................. 6

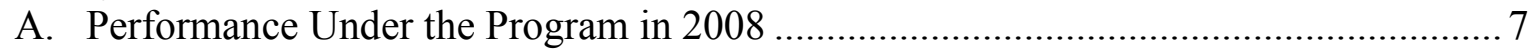

B. Microeconomic Policy Mix for 2009 ................................................................... 9

C. Post-SMP Fund Involvement and Structural Reform Agenda ................................. 11

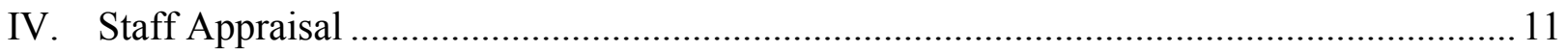

Box

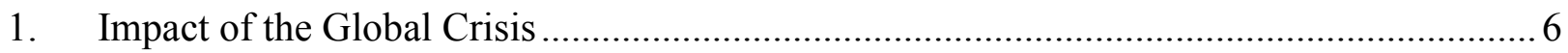

Figure

1. Main Economic Developments, 2006-08 ................................................................. 5

Tables

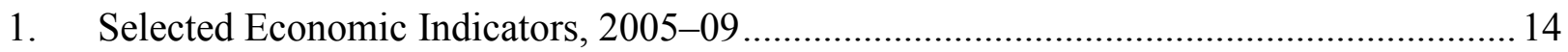

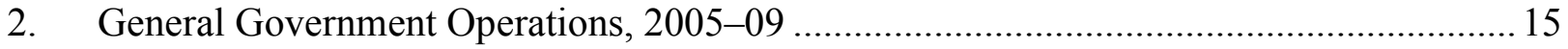

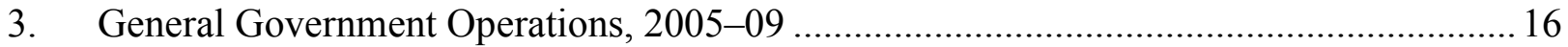

4. Accounts of the National Bank of Tajikistan, 2004-09................................................. 17

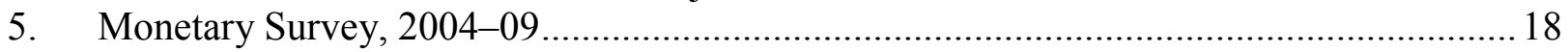

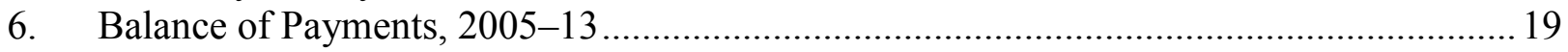

Attachment

I. Letter of Intent 


\section{EXECUTIVE SUMMARY}

Economic developments in 2008 were favorable, but the global slowdown weighs on the 2009 outlook. The ongoing global financial crisis is expected to impact Tajikistan mainly through spillovers from the global slowdown. A direct impact on the financial sector seems unlikely. Real GDP growth should slow in 2009 on account of stagnating remittances and sluggish export growth. Inflation is projected to slow in 2009 , following the expected decline in international commodity prices. Tajikistan's external position is likely to weaken significantly in 2009, after the projected surplus in 2008 that allowed the central bank to build reserves.

\section{Policy discussions:}

- $\quad$ Most end-September quantitative targets under the SMP were met, and prospects for meeting end-December targets are good. Structural reforms are broadly on track.

- $\quad$ The authorities expect to close 2008 with a moderate fiscal surplus (excluding the externally financed public investment program). Helped by strong remittances inflows, the central bank was able to accumulate reserves faster than projected through October 2008.

- $\quad$ The 2009 budget is expansionary, allowing among others for significant increases in capital spending and civil service wages.

- $\quad$ Monetary policy aims to contain monetary growth, while the exchange rate will have to move in line with the market to facilitate external adjustment.

- $\quad$ The authorities would like to move to a PRGF arrangement soon after the completion of the SMP.

\section{Staff appraisal:}

- Staff welcomes the good performance under the SMP, and supports the authorities' policy objectives for the remainder of 2008.

- $\quad$ The authorities' target of a modest fiscal deficit for 2009 is appropriate, but will require expenditure restraint (compared to the budget) or specific revenue measures.

- $\quad$ Exchange rate flexibility will be key to facilitating external adjustment in 2009, if inflows dry up as projected.

- $\quad$ The banking system remains fragile, and the new cotton-financing scheme introduced in 2008 is likely to adversely impact asset quality. 


\section{INTRODUCTION AND BACKGROUND}

1. The main purpose of the SMP is to allow the authorities to reestablish their credibility after a serious episode of misreporting to the Fund. ${ }^{1}$ The SMP provides an appropriate policy framework to secure macroeconomic stability in a difficult external environment, with a view to building a policy track record that could support the authorities' request for a new PRGF arrangement.

2. Performance under the program at end-June was favorable. All end-June indicative targets were met with substantial margins, with one exception: the indicative target related to accumulation of new tax arrears by the state-owned power utility Barki Tajik was missed by a small amount (\$2 million). Good progress was made in implementing key structural benchmarks.

\section{RECENT ECONOMIC DEVELOPMENTS AND OUTLOOK}

3. Economic developments in $\mathbf{2 0 0 8}$ are broadly favorable, despite a severe winter and a difficult crop season. Real GDP growth is likely to reach 7 percent in 2008 (revised upward from 5 percent assumed under the program), mainly driven by remittance-financed demand in the services and construction sectors and non-cotton agricultural production. Inflation has receded from its August peak, and is projected to decline to 16 percent year-onyear in December 2008, helped by the recent retrenchment in international food and fuel prices. $^{2}$ The balance of payments showed a surplus through September 2008, largely because of an increase in remittances by 70 percent over the same period in $2007 .{ }^{3}$

4. External developments are weighing on the outlook for 2009 (Box 1). On the positive side, the global financial crisis has so far had little impact on Tajikistan's financial sector because direct linkages are limited. However, remittances are projected to stagnate, and export demand to wane. As such, staff projects real GDP growth to slow to 5 percent at best in 2009 , with risks to the outlook being largely on the downside. ${ }^{4}$ In particular, remittances could be affected more severely than assumed and decline in absolute terms. Moreover, the ongoing electricity rationing, if exacerbated by another severe winter, could stifle industrial production and agriculture. The recent induction of a new hydropower plant (Sangtuda I) that is estimated to raise total capacity by more than 10 percent should bring some relief in this regard. Inflation is likely to decelerate to

\footnotetext{
${ }^{1}$ See Tajikistan-Staff-Monitored Program (IMF Country Report 08/197) and Republic of Tajikistan-Report on Noncomplying Disbursements and Breach of Obligations Under Article VIII, Section 5.

${ }^{2}$ The lifting of the export ban on wheat by Kazakhstan, the main wheat exporter to Tajikistan, should also help reduce inflationary pressures.

${ }^{3}$ Some of this increase reflects a switch to official channels by remitters.

${ }^{4}$ The authorities thought that growth might still reach 7 percent, pointing to the easing of some supply bottlenecks.
} 
Figure 1. Tajikistan: Main Economic Developments, 2006-08

Activity rebounded in 2008 after a weak first quarter ,...

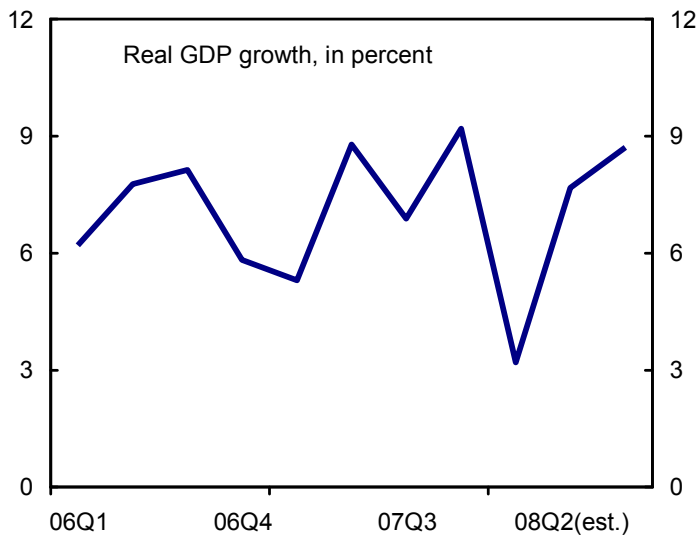

The trade deficit worsened,...

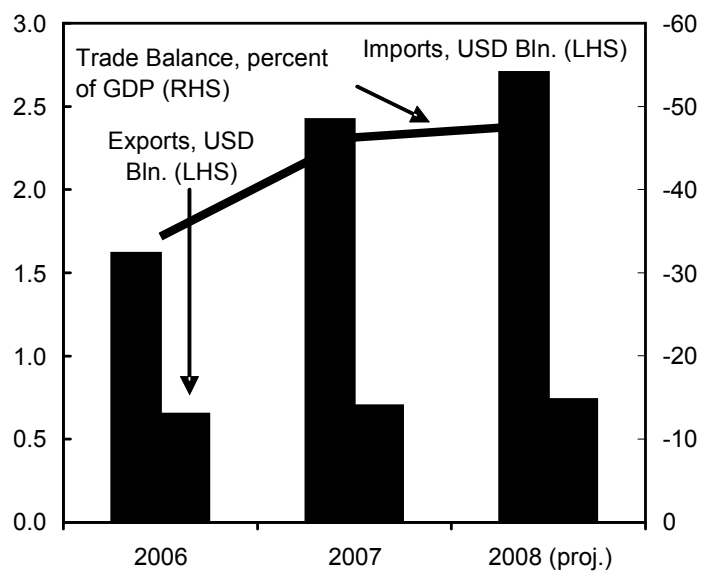

The NBT strengthened its reserves position,...

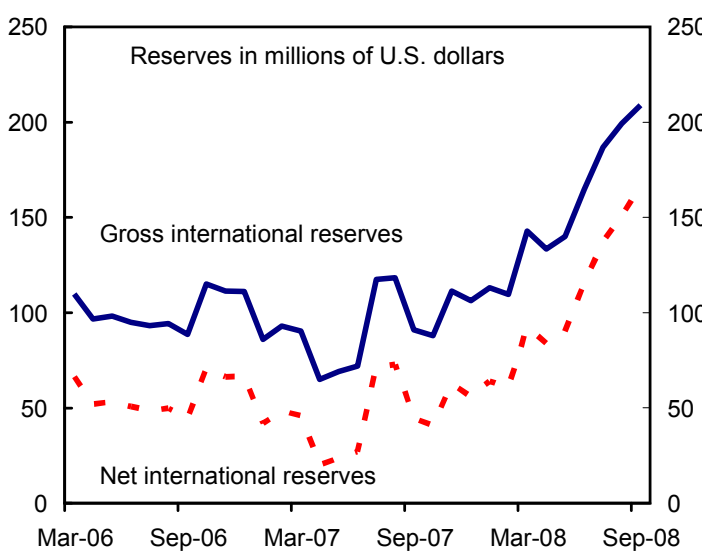

....and inflation has declined from its August peak.
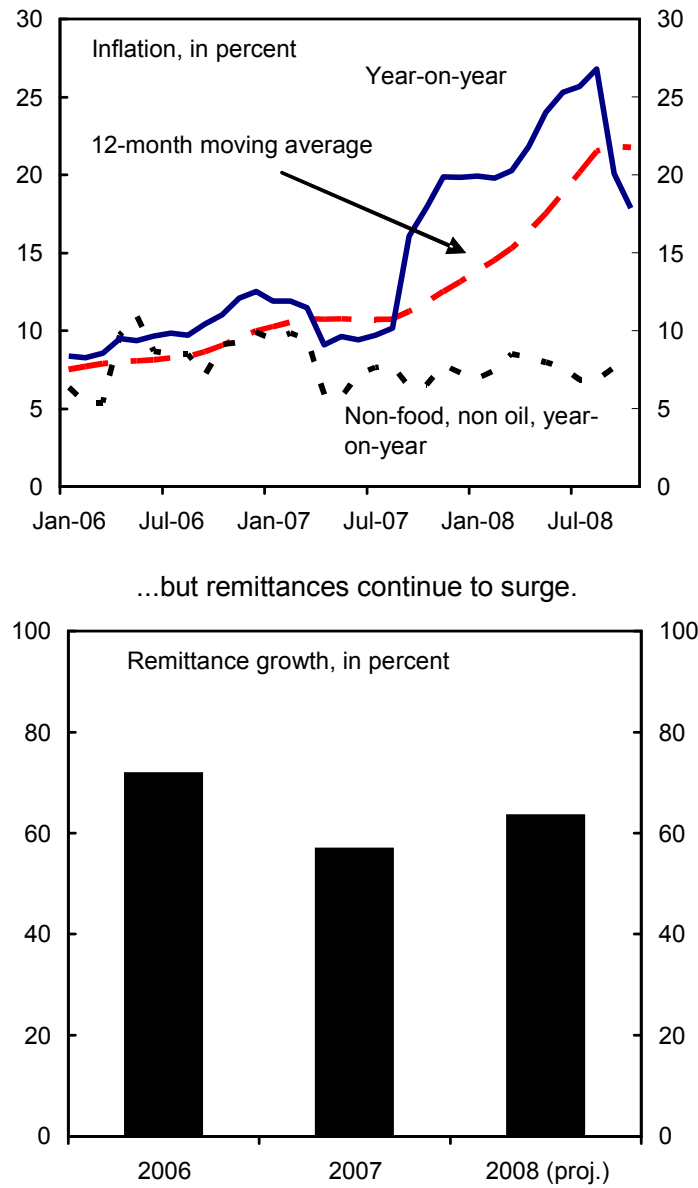

...while keeping the somoni broadly stable against the U.S. dollar.

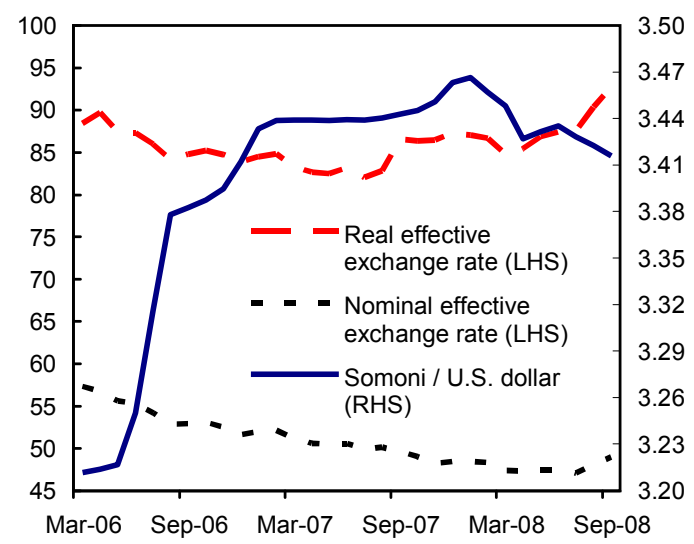

Source: Tajikistan authorities; and Fund staff calculations. 
10-12 percent by December 2009, or even less if international price changes are fully passed through.

\section{Box 1. Tajikistan: Impact of the Global Crisis}

Spillover effects from the global slowdown are expected to dampen growth and worsen Tajikistan's external position. Most importantly, remittances are projected to stagnate due to a slowdown in the two major sources of remittances-Russia and Kazakhstan (an estimated 1 million migrants work in these two countries). Remittances, projected Figure 2. Remittances and Trade Deficit, 2003-2008 at over 40 percent of GDP in 2008 , have been the largest source of current inflows during the last several years, supporting domestic demand and allowing the NBT to accumulate reserves. In addition, export growth is projected to decline, mainly reflecting falling demand and international prices for cotton, Tajikistan's major export. ${ }^{1}$

These adverse effects on the external current account would (in billions of US dollars, unless otherwise indicated)

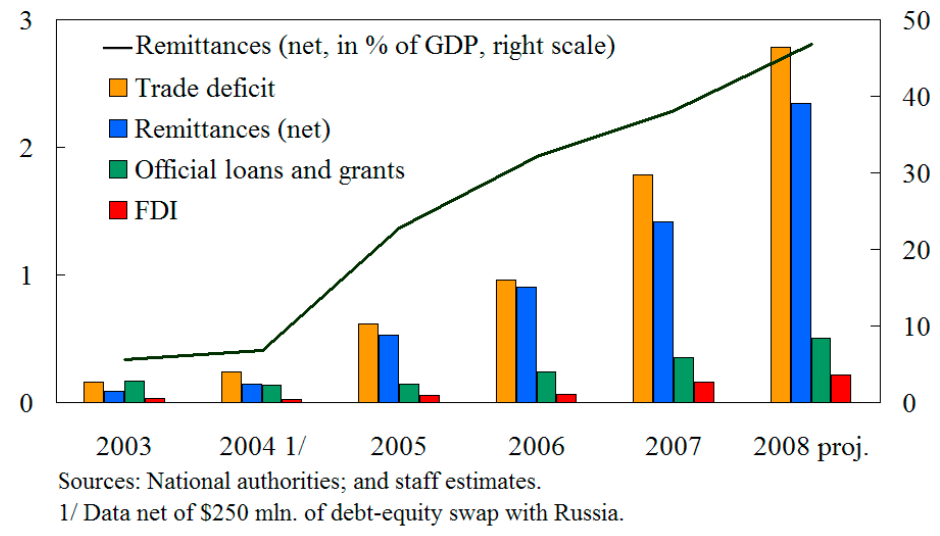
only be partly offset by the projected decline in international food and fuel prices. There are also some reports of foreign direct investments being delayed, and trade credit drying up.

Tajikistan's financial sector has limited linkages to global financial markets. The sector consists mostly of commercial banks, and is funded primarily by local deposits and capital. ${ }^{2}$ One foreign-owned bank operates in Tajikistan, and its capital constitutes around 20 percent of total banking sector capital. Banks' profitability could decline as remittances slow, since the associated fee income constitute around one-third of total income. Deposit growth may also be affected by slowing remittances or a spillover of declining confidence in banks from other countries in the region.

${ }^{1}$ The projected decline in international aluminum price would not affect Tajikistan's exports because, under the tolling arrangement, the aluminum smelter receives a fixed fee which has shown little correlation with international prices. The offshore counterparty to the tolling arrangement is thus buffering price movements. However, there could be a quantity effect, if global demand for aluminum falls.

${ }^{2}$ Around $1 \frac{1}{2}$ percent of banks' liabilities is external debt with a specific clause that would allow the creditor to request early repayment.

\section{Policy Discussions}

\section{Policy discussions focused on two issues:}

- $\quad$ Performance under the program in 2008; and

- $\quad$ The macroeconomic policy mix for 2009. 
In addition, the authorities reiterated their request for a PRGF arrangement in early 2009 after completion of the SMP.

\section{A. Performance under the Program in 2008}

6. Performance under the program is broadly favorable. The authorities met most quantitative targets for end-September, and took key structural measures. Prospects for meeting their end-December targets are good.

7. The overall fiscal balance (excluding the externally financed public investment program, PIP) registered a surplus through September 2008, higher than programmed. Revenue collection was stronger than projected, mostly reflecting high nominal growth and imports. Disbursements of concessional external financing under the PIP exceeded the program ceiling because existing projects moved faster than anticipated. The authorities emphasized that this merely reflected a frontloading of disbursements and not new borrowing. Taken together, the overall deficit widened to 4.5 percent of annual GDP, while total public and publicly guaranteed debt declined to 30 percent of annual GDP.

8. The authorities should achieve a modest overall fiscal surplus for 2008 as a whole, thus again exceeding program expectations. The revenue overperformance is likely to continue, and the authorities are committed to maintaining strict expenditure control. This should yield an overall surplus (excluding the PIP) of 1 percent of GDP compared to the program target of a balanced budget. In light of the faster disbursement of concessional external financing through September, staff agreed with the authorities to raise the end-December ceiling to accommodate the availability of financing and move ahead with planned investment projects.

9. The NBT was able to build net international reserves through September ahead of program projections. Since the beginning of the year, net international reserves increased by $\$ 111$ million to $\$ 167$ million at end-September. ${ }^{5}$ The surge in remittances allowed the NBT to buy foreign exchange and thus satisfy demand for somoni liquidity from the banking system. With the interbank market still developing, and in the absence of an effective monetary policy instrument, the authorities see unsterilized foreign exchange purchases as the most effective means for liquidity provision. In addition, they are concerned about competitiveness, and interventions served to keep the somoni broadly stable against the U.S. dollar - the somoni appreciated by about 2 percent in 2008 to date. Helped by the fiscal overperformance, net domestic assets of the NBT were contained below program.

10. Reserve accumulation is likely to be reversed in the fourth quarter. The authorities thought that money demand had been underestimated somewhat in the program,

\footnotetext{
${ }^{5}$ Gross and net reserves exclude pledged deposits of the NBT. Following a retention in June of a pledged \$25 million deposit from the NBT for an unrepaid loan, the same foreign creditor retained pledged deposits in the amount of $\$ 125$ million in September. The remaining \$91 million were settled in October, ahead of schedule. NBT guarantees of over $\$ 70$ million remain outstanding.
} 
partly because nominal growth was higher than initially projected. At the same time, remittance growth showed first signs of slowing in October. On balance, reserve money growth for 2008 has been revised upward, and the authorities were confident that this was consistent with their objective of reducing inflation, also given that international food and fuel prices are projected to decline. In light of the overperformance so far, the authorities agreed to raise the end-December program floor on net international reserves. They expect to keep net domestic assets of the NBT below program, given the projected fiscal outturn.

\section{Arrears remain a problem, though the authorities have largely succeeded in} avoiding new gross arrears. As at end-June, Barki Tajik missed the indicative target on nonaccumulation of new tax arrears in September. New arrears arose largely from noncollection from consumers, including the ministry of land and water resources, and the nonpayment of penalties to the Revenue Authority on the outstanding stock of arrears. The authorities noted that tax arrears are part of a complex problem of cross arrears and also related to the debt overhang of cotton farmers. ${ }^{6}$ They believe that the arrears problem can only be solved over time, but intend to raise penalties as a first step, since many firms reportedly abuse tax arrears as a cheap source of financing.

\section{Outside the agricultural sector, the authorities have made good progress on implementing structural reforms, and completed the end-September structural benchmarks on time:}

- $\quad$ The NBT has selected Ernst\&Young London to conduct the special audit of the NBT. The auditors have completed the on-site field work, and plan to deliver a draft report to the NBT in late December. They briefed staff on their work so far, but had not yet finalized their assessment. Once the special audit is finished, the annual external audits of the NBT for 2006-08 need to be completed.

- $\quad$ The authorities have prepared a first draft of the amendments to the NBT and commercial banking laws with assistance from the World Bank. The drafting has taken longer than envisaged, in part because the initial plan to fully redraft the laws instead of only making the amendments under the program (an end-December benchmark) did not prove feasible within the short time frame. The authorities have thus reverted to first amending the existing law to address the key recommendations from the Financial Stability Assessment Program (FSAP) report. They now plan to submit the amendments to parliament in March 2009.

- The terms of reference for the audit of Talco, the state-owned aluminum smelter, by an internationally reputable auditing firm, was issued in September (benchmark). The audit of the state electricity company Barki Tajik has been concluded, but the auditor has not been able to give an opinion on the 2007 financial statement because of

\footnotetext{
${ }^{6}$ For example, a part of Barki Tajik's outstanding stock of arrears reflects arrears of the state-owned aluminum company (Talco) to Barki Tajik.
} 
missing information and other concerns. The government and the World Bank are now analyzing the findings in the context of the World Bank's Energy Loss Reduction Project.

- The government issued a decree establishing a supervision unit in the ministry of finance for regular monitoring of the financial operations of the 10 largest stateowned enterprises in September (benchmark). The authorities have requested technical assistance from the Fund to make the unit operational. ${ }^{7}$

- The authorities are preparing legislative changes for establishing a contingent liability reporting regime to cover state-owned enterprises, public institutions and the NBT with the assistance of the FAD regional adviser (end-December benchmark).

- $\quad$ Agricultural sector reforms, in particular in the cotton sector, are progressing only slowly, but remain essential to reduce one of Tajikistan's key vulnerability and growth obstacle. The authorities have drafted a decree stipulating the abolishment of cotton export licensing by the NBT which is now pending government approval. The NBT reported that negotiations with foreign creditors over guarantees are ongoing. In one case, they were successful in securing at least partial payment by the debtor. The authorities confirmed their intention of settling all guarantees to foreign banks in a timely fashion, while seeking to maximize loan recoveries from cotton investors.

- $\quad$ On October 28, 2008, the government adopted a three-year debt management strategy that sets an external debt ceiling of 40 percent of GDP. Based on existing borrowing plans, total public and publicly-guaranteed external debt is projected to reach 31 percent of GDP at end-2008. ${ }^{8}$ As such, the debt strategy's ceiling can accommodate additional projects, and is unlikely to be binding in the next year. The ceiling is, however, consistent with the recommendations from the last DSA (IMF Country Report 07/144).

\section{B. Macroeconomic Policy Mix for 2009}

\section{The projected global slowdown clouds the economic outlook for Tajikistan. On} the positive side, the expected decline in international food and fuel prices should contribute to a notable decline in headline inflation. ${ }^{9}$ Moreover, such a fall in international food prices should provide some relief to poor households, since Tajikistan imports almost all of its food. However, a marked slowdown in economic growth on account of external factors is projected

\footnotetext{
${ }^{7}$ The European Commission has indicated its willingness to finance a consultant for the technical assistance.

${ }^{8}$ In addition, the Ministry of Energy has recently signed a new Memorandum of Understanding with Sinohydro (China) for the construction of a new hydro power plant. The agreement is still to be officially endorsed by the government. No financing contract (for about $\$ 200$ million) has been signed yet, but it is expected that its terms would be concessional.

${ }^{9}$ Food products account for 60 percent and fuel products for another $2 \frac{1 / 2}{2}$ percent of the CPI basket.
} 
to dampen economic activity, while stagnating remittances and sluggish exports are expected to weaken Tajikistan's external position. As such, the authorities aim for a modestly countercyclical macroeconomic policy mix. Fiscal policy will support activity, significantly raising expenditures while not taking any notable revenue measures. Monetary policy will be passive in the absence of an effective monetary policy instrument, while the exchange rate will need to facilitate external adjustment.

\section{The 2009 budget targets an overall deficit (excluding the PIP) of $1 / 2$ percent of} GDP. Given Tajikistan's development needs, the authorities intend to raise spending by around 25 percent in real terms, mostly for domestically financed capital spending, but also reflecting civil service wage increases. ${ }^{10}$ Expenditure on health and education will see large increases of 45 percent and 35 percent in real terms, respectively, albeit from a low base and mostly on account of wages. The budget also provides for continued financing of cotton farmers, via on-lending by commercial banks. The authorities project an increase in revenues by around 2 percent of GDP that would largely stem from improvements in revenue administration. Staff cautioned that this may be difficult to achieve without specific measures and projects an overall deficit of 1 percent of GDP in 2009, absent further measures. The authorities intend to finance the deficit from domestic sources by drawing down deposits at the NBT, privatization proceeds, and issuing a small amount of government securities. ${ }^{11}$

\section{The authorities see little scope for further enhancing their reserves position in}

2009. They expect the excess supply of foreign exchange to fade, and will let the exchange rate move with market trends, following an asymmetric intervention strategy. To achieve their inflation objective, they aim to reduce broad money growth and will constrain reserve money growth accordingly. Reserve money growth itself will come mainly from the government drawing down its deposits at the NBT, and the authorities remain committed to refrain from direct lending to banks or the economy. They anticipate liquidity shortages to continue, and some banks may reduce their excess reserves.

\section{The new cotton financing scheme that was introduced in 2008 could impact} banks' asset quality as of 2009. Under the scheme, the government provides funds to commercial banks who then on-lend to cotton farmers at negative real interest rates. The credit risk remains with commercial banks which have also made additional loans to the agricultural sector from their own funds. Some scheduled repayments have been received in October 2008, but the bulk is expected to start in the spring of 2009. With the international cotton market weakening, many farmers - who are, in many cases, already highly indebtedmay not be in a position to service those new loans.

\footnotetext{
${ }^{10}$ Around $\$ 160$ million are allocated for the construction of the Roghun hydropower plant alone.

${ }^{11}$ Under staff projections, government deposits at the NBT would be depleted in about three years.
} 


\section{Post-SMP Fund Involvement and Structural Reform Agenda}

17. The authorities reiterated their intention to move to a PRGF arrangement soon after the completion of the SMP. They appreciated the Fund's ongoing involvement, stressing that Fund advice has helped them maintain macroeconomic stability as well as a reform momentum. They were concerned that Tajikistan's external position would be fragile in 2009, and wanted to benefit from the stability that a Fund financial arrangement could bring. In this regard, the authorities noted that budget support from the Asian Development Bank, the World Bank, and the European Union has been put on hold pending the successful completion of the SMP and the initiation of negotiations for a PRGF.

\section{With their 2009 structural reform agenda, the authorities seek to strengthen} public institutions and ease growth bottlenecks. The results of the ongoing special audit of the NBT will be used to further strengthen its governance, and the authorities intend to improve the NBT's balance sheet to facilitate monetary policy execution. State-owned enterprises are still a dominant part of the economy, and the new monitoring unit in the ministry of finance will work to enhance transparency and management to ensure that these enterprises are put on a sound financial footing, and share the burden of taxation. Audits of key SOEs should be used to further develop the reform agenda. The authorities plan to continue revenue administration reforms to raise the revenue yield and strengthen the business environment. Ongoing public financial management reforms will seek to ensure that budget allocations reflect policy priorities and expenditures are carried out in a cost-effective manner. With World Bank assistance, the authorities are finalizing their strategy to resolve the domestic cotton debt problem before the next harvest season, which is key to the sector's viability. In addition, there is a need to develop a sustainable financing model for the sector that is free from government interference.

\section{StAfF APPRAisal}

\section{Staff welcomes the good performance under the SMP through end-September}

2008. In particular, the substantial increase in net international reserves above program objectives is an important step toward reducing external vulnerabilities. Moreover, the cautious approach to fiscal policy, saving the revenue overperformance, allowed the government to increase its deposits with the NBT. This helped constrain reserve money growth and should reduce inflationary pressures going forward. However, the continued accumulation of tax arrears by Barki Tajik is regrettable, and the authorities need to address the underlying problems at the state-owned power utility and prevailing cross-arrears urgently. The results of the ongoing audits of the NBT and Talco, as well as the completed audit of Barki Tajik should help design reforms to enhance governance and transparency.

20. The authorities are well placed to achieve their end-December 2008 targets. Staff commends the authorities for raising the net international reserves target under the program despite the projected slowdown in remittances inflows. Fiscal policy needs to stay the course, 
saving the projected revenue overperformance and keeping expenditures within budget limits, which is needed to contain money growth. Staff agrees with the proposed increase of the program ceiling on disbursements of concessional external financing since it only reflects a faster execution of existing projects and does not affect debt sustainability. The expected delay in making certain legal changes to the NBT and commercial banking laws to strengthen governance is unfortunate, and staff urges the authorities to submit the needed amendments to parliament as soon as possible.

21. Fiscal policy will be the main instrument to support domestic activity in 2009. In light of the projected growth slowdown, the targeted overall deficit (excluding the PIP) of $1 / 2$ percent of GDP is appropriate. However, achieving this may require some expenditure restraint relative to the budget or specific revenue measures. Much of the increase in expenditures is intended for energy projects_-given the country's large infrastructure needs - but individual projects need to be closely scrutinized to ensure cost effectiveness and debt sustainability. A somewhat less ambitious increase in capital expenditures would help to safeguard the authorities' deficit target.

\section{Monetary and exchange rate policies will have to focus on maintaining external}

stability. With weaker remittance inflows, pressures could arise in the foreign exchange market. And while improved, the NBT's international reserves position is not sufficient to defend the exchange rate. Thus, the somoni will have to be allowed to move in line with market trends. The NBT aims to contain money growth to reduce inflation. However, without an effective direct monetary policy instrument, the NBT has limited scope to exert control over monetary developments or stabilize economic activity. This points to the need to develop and deepen the market for government securities or NBT bills, and strengthen the functioning of the interbank market in line with recommendations from the FSAP.

\section{There is a need to step up supervision to safeguard the banking system's} soundness. The risk of a spillover from the global financial crisis to Tajikistan's banking system is low, given that direct linkages are limited. Still, the NBT needs to monitor banks carefully to detect early any deterioration in their balance sheets. More generally, the NBT needs to watch financial soundness indicators closely, and ensure that banks, without any exceptions, fully comply with reserve requirements. Strengthening the existing deposit insurance system with ongoing assistance from the World Bank should help maintain depositor confidence. The authorities also need to closely monitor banks' exposure to the agricultural sector, and particularly to the cotton sector, where loan portfolios have expanded rapidly since 2007 .

24. Risks to the outlook stem largely from external developments. Most importantly, remittances could fall in absolute terms in 2009 (rather than just stagnate as in staff's baseline scenario). This would require significant external adjustment while further curtailing a key income source for many households living below the poverty line. Fiscal policy would need to react flexibly and provide relief, even in the absence of an effective social safety net 
and there may be a need to revisit spending priorities and the deficit target, e.g., by maintaining the expenditure envelope while allowing for revenue shortfalls. Monetary and exchange rate policy would need to let the somoni move with market trends. Moreover, a possible sharp depreciation of main trading partners' currencies may require further exchange rate adjustment. In addition, banks' balance sheets and profitability could be hit, e.g., due to a worsening of asset quality in case of further decline in international cotton prices, or a loss of fee income. 
Table 1. Tajikistan: Selected Economic Indicators, 2005-09

\begin{tabular}{|c|c|c|c|c|c|c|c|}
\hline & \multirow{2}{*}{$\begin{array}{r}2005 \\
\text { Act. }\end{array}$} & \multirow{2}{*}{$\begin{array}{r}2006 \\
\text { Act. }\end{array}$} & \multirow{2}{*}{$\begin{array}{c}2007 \\
\text { Est. }\end{array}$} & \multicolumn{2}{|c|}{2008} & \multicolumn{2}{|c|}{2009} \\
\hline & & & & Prog. & Rev. Proj. & $\begin{array}{c}\text { IMF CR } \\
08 / 197\end{array}$ & Proj. \\
\hline \multicolumn{8}{|c|}{ (Annual percent change, unless otherwise indicated) } \\
\hline \multicolumn{8}{|l|}{ National accounts } \\
\hline $\begin{array}{l}\text { Real GDP } \\
\text { GDP deflator (cumulative) }\end{array}$ & $\begin{array}{l}6.7 \\
9.6\end{array}$ & $\begin{array}{r}7.0 \\
20.3\end{array}$ & $\begin{array}{r}7.8 \\
27.9\end{array}$ & $\begin{array}{r}5.0 \\
20.2\end{array}$ & $\begin{array}{r}7.0 \\
25.6\end{array}$ & $\begin{array}{r}7.0 \\
\ldots\end{array}$ & $\begin{array}{r}5.0 \\
18.5\end{array}$ \\
\hline $\mathrm{CPI}$ inflation (end-of-period) & 7.1 & 12.5 & 19.8 & 15.0 & 16.0 & 9.0 & 11.0 \\
\hline $\mathrm{CPI}$ inflation (period average) & 7.3 & 10.0 & 13.2 & 18.5 & 21.0 & $\ldots$ & 12.8 \\
\hline \multicolumn{8}{|c|}{ (In percent of GDP) } \\
\hline \multicolumn{8}{|l|}{ Investment and savings $1 /$} \\
\hline Investment & 14.8 & 13.7 & 22.0 & 20.8 & 20.6 & 18.1 & 20.1 \\
\hline of which :Fixed capital investment & 13.8 & 12.8 & 21.1 & 20.0 & 19.8 & 17.3 & 19.1 \\
\hline Government & 7.8 & 6.8 & 14.1 & 14.0 & 13.8 & 11.3 & 13.1 \\
\hline Private & 6.0 & 6.0 & 7.0 & 6.0 & 6.0 & 6.0 & 6.0 \\
\hline Gross national savings & 12.1 & 10.9 & 10.9 & 10.9 & 11.3 & 10.0 & 11.3 \\
\hline Public & 4.9 & 8.5 & 7.9 & 6.1 & 6.5 & 4.8 & 5.9 \\
\hline Private & 7.2 & 2.4 & 2.9 & 4.8 & 4.8 & 5.1 & 5.4 \\
\hline \multicolumn{8}{|c|}{ (In percent of GDP) } \\
\hline \multicolumn{8}{|l|}{ Public Finances } \\
\hline $\begin{array}{l}\text { Revenue and grants } 2 / \\
\text { Of which: tax revenue }\end{array}$ & $\begin{array}{l}20.1 \\
16.6\end{array}$ & $\begin{array}{l}23.6 \\
16.5\end{array}$ & $\begin{array}{l}21.6 \\
17.8\end{array}$ & $\begin{array}{l}22.4 \\
18.5\end{array}$ & $\begin{array}{l}21.9 \\
18.7\end{array}$ & $\begin{array}{l}22.6 \\
19.1\end{array}$ & $\begin{array}{l}22.9 \\
19.6\end{array}$ \\
\hline Expenditure and net lending & 23.0 & 21.9 & 27.8 & 30.4 & 29.2 & 29.1 & 30.1 \\
\hline Of which: current & 15.1 & 15.0 & 13.6 & 15.4 & 14.5 & 16.9 & 16.1 \\
\hline capital & 7.8 & 6.8 & 14.1 & 14.0 & 13.8 & 11.3 & 13.1 \\
\hline Overall balance (excluding Public Investment Program) 2/ & 0.5 & 0.8 & 1.6 & 0.0 & 1.0 & 0.0 & -1.2 \\
\hline Overall balance (including Public Investment Program) & -2.9 & 1.7 & -6.2 & -8.0 & $\begin{array}{r}-7.3 \\
-7.3\end{array}$ & -6.4 & -7.2 \\
\hline Domestic financing & 0.3 & -3.3 & -0.7 & 0.8 & -0.3 & 0.0 & 1.5 \\
\hline External financing & 2.6 & 1.6 & 6.9 & 7.2 & 7.6 & 6.4 & 5.8 \\
\hline \multicolumn{8}{|c|}{ (12-month growth in percent of broad money, unless otherwise indicated) } \\
\hline \multicolumn{8}{|l|}{ Monetary sector } \\
\hline Net foreign assets of the banking sector & -70.3 & 25.1 & 4.8 & 7.7 & -20.8 & -14.9 & -0.30 \\
\hline Net domestic assets of the banking sector, including bills payable & 100.4 & 38.3 & 74.0 & 16.8 & 53.8 & 58.2 & 24.7 \\
\hline Broad money & 30.2 & 63.4 & 78.8 & 24.7 & 33.0 & 24.8 & 24.4 \\
\hline Reserve money (12-month percent change) & 29.2 & 49.2 & 40.3 & 24.1 & 27.3 & 18.5 & 22.7 \\
\hline Velocity of broad money (eop) & 7.7 & 6.1 & 4.7 & 4.7 & 4.7 & 4.5 & 4.7 \\
\hline Interest rate (weighted average NBT bill rate, in percent) & 7.0 & 7.7 & 7.3 & $\ldots$ & $\ldots$ & $\ldots$ & $\ldots$ \\
\hline \multicolumn{8}{|c|}{ (In percent of GDP, unless otherwise indicated) } \\
\hline \multicolumn{8}{|l|}{ External sector $3 /$} \\
\hline Exports of goods and services (in U.S. dollar, percent change) & $\ldots$ & 9.1 & 16.9 & 11.6 & 16.1 & 4.8 & 5.3 \\
\hline Imports of goods and services (in U.S. dollar, percent change) & & 32.5 & 57.9 & 24.8 & 42.4 & 5.3 & 3.3 \\
\hline Current account balance & -2.7 & -2.8 & -11.2 & -10.0 & -9.3 & -8.1 & -8.8 \\
\hline $\begin{array}{l}\text { Trade balance } \\
\text { FDI }\end{array}$ & $\begin{array}{r}-26.9 \\
2.4\end{array}$ & $\begin{array}{r}-35.1 \\
2.3\end{array}$ & $\begin{array}{r}-45.1 \\
4.3\end{array}$ & $\begin{array}{r}-50.9 \\
4.2\end{array}$ & $\begin{array}{r}-50.5 \\
3.8\end{array}$ & $\begin{array}{r}-46.7 \\
3.6\end{array}$ & $\begin{array}{r}-42.9 \\
1.6\end{array}$ \\
\hline Total public and publicly guaranteed external debt & 38.8 & 32.4 & 33.2 & 34.7 & 31.0 & 35.9 & 30.4 \\
\hline Gross official reserves (in U.S. dollars) $4 /$ & 91 & 111 & 107 & 169 & 198 & 229.0 & 187.8 \\
\hline in months of next year's imports $5 /$ & 0.9 & 0.7 & 0.4 & 0.8 & 0.8 & 1.0 & 0.7 \\
\hline in percent of broad money & 0.3 & 0.2 & 0.1 & 0.1 & 0.2 & $\ldots$ & 0.1 \\
\hline \multicolumn{8}{|l|}{ Memorandum items: } \\
\hline Nominal GDP (in millions of somoni) & 7,201 & 9,272 & 12,780 & 16,135 & 17,178 & 19,337 & 21,373 \\
\hline Nominal GDP (in millions of U.S. dollars) & 2,311 & 2,811 & 3,712 & 4,300 & 5,014 & 4,995 & 6,107 \\
\hline Nominal effective exchange rate (Index $2000=100$ ) & 58.7 & 54.8 & 50.2 & $\ldots$ & $\ldots$ & $\ldots$ & $\ldots$ \\
\hline Real effective exchange rate (Index $2000=100)$ & 58.7 & 54.8 & 50.2 & $\ldots$ & $\ldots$ & $\ldots$ & $\ldots$ \\
\hline Average exchange rate (somoni per U.S. dollar) & 3.12 & 3.30 & 3.44 & $\ldots$ & $\ldots$ & $\ldots$ & $\ldots$ \\
\hline
\end{tabular}

Sources: Data provided by the Tajikistan authorities; and Fund staff estimates.

1/ Private investment and savings are estimates. Investment includes changes in stocks.

2/ 2006 overall balance excludes the MDRI debt relief that is reflected in grants. PIP expenditure includes investment financed by loans from China.

3/ Starting from 2005, the export and import figures reflect the transition to tolling arrangement for aluminum exports.

Therefore, the export and import figures are lower than earlier years.

4/ Gross reserves are net of the pledged deposits of the NBT.

5/ Excluding electricity, which is on barter basis, and imports related to projects financed with loans from China. 
Table 2. Tajikistan: General Government Operations, 2005-09

(In percent of GDP; unless otherwise indicated)

\begin{tabular}{|c|c|c|c|c|c|c|c|c|c|}
\hline & \multirow{3}{*}{$\begin{array}{r}2005 \\
\text { Act. }\end{array}$} & \multirow{3}{*}{$\begin{array}{r}2006 \\
\text { Act. }\end{array}$} & \multirow{3}{*}{$\begin{array}{r}2007 \\
\text { Est. }\end{array}$} & \multicolumn{4}{|c|}{2008} & \multirow{2}{*}{\multicolumn{2}{|c|}{$\frac{2009}{\text { Year }}$}} \\
\hline & & & & \multicolumn{2}{|c|}{ End-Sept. } & \multicolumn{2}{|c|}{ Year } & & \\
\hline & & & & Prog. & Est. & Prog. & Rev. Proj. & Proj. & Budget \\
\hline Overall revenues and grants & 20.1 & 23.6 & 21.6 & 15.3 & 15.9 & 22.4 & 21.9 & 22.9 & 24.4 \\
\hline Total revenues & 19.3 & 18.9 & 20.5 & 14.3 & 15.4 & 20.7 & 20.9 & 21.5 & 23.0 \\
\hline Tax revenues & 16.6 & 16.5 & 17.8 & 13.0 & 14.1 & 18.5 & 18.7 & 19.6 & 20.6 \\
\hline Income and profit tax & 2.1 & 2.1 & 2.4 & 1.7 & 1.9 & 2.4 & 2.5 & 2.9 & 3.2 \\
\hline Payroll taxes & 2.1 & 2.0 & 2.0 & 1.4 & 1.4 & 2.0 & 2.0 & 2.2 & 2.3 \\
\hline Property taxes & 0.0 & 0.8 & 0.7 & 0.6 & 0.5 & 0.8 & 0.8 & 0.8 & 0.8 \\
\hline Taxes on goods and services & 9.4 & 9.7 & 10.9 & 8.1 & 8.9 & 11.5 & 11.6 & 11.8 & 12.6 \\
\hline VAT & 6.8 & 7.3 & 8.3 & 6.2 & 6.8 & 8.9 & 8.9 & 9.2 & 9.8 \\
\hline Excises and other internal indirect taxes & 2.5 & 2.5 & 2.6 & 1.9 & 2.2 & 2.7 & 2.7 & 2.6 & 2.9 \\
\hline International trade and operations tax & 2.1 & 1.8 & 1.8 & 0.8 & 1.3 & 1.7 & 1.8 & 1.8 & 1.7 \\
\hline Non-tax revenues & 2.7 & 2.4 & 2.7 & 1.3 & 1.3 & 2.3 & 2.2 & 1.9 & 2.4 \\
\hline Grants 1/ & 0.7 & 4.7 & 1.1 & 0.9 & 0.5 & 1.7 & 1.0 & 1.3 & 1.4 \\
\hline Of which: PIP financing & 0.0 & 0.6 & 0.8 & 0.9 & 0.5 & 1.2 & 1.0 & 1.0 & 1.0 \\
\hline Total expenditures and lending minus repayments & 23.0 & 21.9 & 27.8 & 20.3 & 20.4 & 30.4 & 29.2 & 30.1 & 29.5 \\
\hline Current expenditures & 15.1 & 15.0 & 13.6 & 10.1 & 9.5 & 15.4 & 14.5 & 16.1 & 16.7 \\
\hline Expenditures on goods and services & 10.4 & 10.4 & 9.4 & 17.0 & 6.3 & 10.9 & 10.0 & 12.0 & 12.4 \\
\hline Wages and salaries & 3.7 & 4.1 & 4.1 & 3.3 & 2.8 & 4.6 & 4.3 & 5.1 & 5.3 \\
\hline Others & 6.7 & 6.3 & 5.3 & 4.0 & 3.4 & 6.3 & 5.7 & 6.9 & 7.1 \\
\hline Interest payments & 0.5 & 0.5 & 0.5 & 0.4 & 0.3 & 0.6 & 0.5 & 0.5 & 0.5 \\
\hline Transfers and subsidies & 4.2 & 4.1 & 3.8 & 2.5 & 3.0 & 3.9 & 4.0 & 3.6 & 3.8 \\
\hline Capital expenditures & 7.8 & 6.8 & 14.1 & 9.6 & 10.0 & 14.0 & 13.8 & 13.1 & 11.9 \\
\hline Externally financed PIP & 3.4 & 3.1 & 8.6 & 6.5 & 7.0 & 9.2 & 9.3 & 7.0 & 5.6 \\
\hline Of which: with loans from China & 0.0 & 0.0 & 5.8 & 6.5 & 5.4 & 5.2 & 5.6 & 3.2 & 1.8 \\
\hline Domestically financed & 4.4 & 3.7 & 5.5 & 3.0 & 3.1 & 4.8 & 4.5 & 6.1 & 6.3 \\
\hline Lending minus repayments 2 / & 0.1 & 0.1 & 0.1 & 0.7 & 0.9 & 0.9 & 0.8 & 0.8 & 0.9 \\
\hline Statistical discrepancy & 0.2 & 0.2 & 0.6 & -0.1 & 0.5 & $\ldots$ & $\ldots$ & $\ldots$ & $\ldots$ \\
\hline Overall balance (incl. PIP) & -2.9 & 1.7 & -6.2 & -5.1 & -4.5 & -8.0 & -7.3 & -7.2 & -5.1 \\
\hline Overall balance (excl. PIP and PIP related grants) 3/ & 0.5 & 0.8 & 1.6 & 0.5 & 1.9 & 0.0 & 1.0 & -1.2 & -0.5 \\
\hline Total financing (incl. PIP) & 2.9 & -1.7 & 6.2 & 5.1 & 4.5 & 8.0 & 7.3 & 7.2 & 5.1 \\
\hline Net external & 2.6 & 1.6 & 6.9 & 5.0 & 5.8 & 7.2 & 7.6 & 5.8 & 5.7 \\
\hline Disbursements & 3.6 & 2.9 & 7.8 & 5.6 & 6.5 & 8.1 & 8.3 & 6.1 & 6.3 \\
\hline Program loans & 0.2 & 0.4 & 0.0 & 0.0 & 0.0 & 0.1 & 0.0 & 0.1 & 0.0 \\
\hline Project loans & 3.4 & 2.5 & 7.8 & 5.6 & 6.5 & 8.0 & 8.3 & 6.0 & 6.3 \\
\hline Amortization & -1.1 & -1.3 & -0.8 & -0.6 & -0.7 & -0.9 & -0.7 & -0.4 & -0.5 \\
\hline Net domestic & 0.3 & -3.3 & -0.7 & 0.1 & -1.2 & 0.8 & -0.3 & 1.5 & -0.6 \\
\hline NBT & -0.2 & -4.1 & -1.1 & -0.1 & -1.4 & 0.5 & 0.0 & 1.3 & -0.8 \\
\hline Commercial banks & -0.1 & 0.0 & -0.4 & 0.2 & -0.4 & 0.1 & -0.3 & 0.1 & 0.1 \\
\hline Gross proceeds from privatization & 0.5 & 0.6 & 0.1 & 0.1 & 0.1 & 0.2 & 0.1 & 0.1 & 0.1 \\
\hline \multicolumn{10}{|l|}{ Memorandum items: } \\
\hline Nominal GDP (in millions of somoni) & 7,201 & 9,272 & 12,780 & $\ldots$ & $\ldots$ & 16,135 & 17,178 & 21,373 & 20,665 \\
\hline Total public and publicly-guaranteed debt & 42.3 & 35.5 & 34.8 & $\ldots$ & $\ldots$ & 35.8 & 31.8 & 32.1 & $\ldots$ \\
\hline
\end{tabular}

Sources: Tajik authorities; and Fund staff estimates.

1/ 2006 grants figure includes the MDRI debt relief of 3.5 percent of GDP.

2/ Includes SM140 mn lending to the cotton sector in 2008, and SM170 mn for 2009.

$3 / 2006$ overall balance excludes the MDRI debt relief that is reflected in grants. 
Table 3. Tajikistan: General Government Operations, 2005-09 (In millions of somoni; unless otherwise indicated)

\begin{tabular}{|c|c|c|c|c|c|c|c|c|c|}
\hline & \multirow{3}{*}{$\begin{array}{l}2005 \\
\text { Act. }\end{array}$} & \multirow{3}{*}{$\begin{array}{l}2006 \\
\text { Act. }\end{array}$} & \multirow{3}{*}{$\begin{array}{r}2007 \\
\text { Est. }\end{array}$} & \multicolumn{4}{|c|}{2008} & \multirow{2}{*}{\multicolumn{2}{|c|}{$\begin{array}{c}2009 \\
\text { Year }\end{array}$}} \\
\hline & & & & \multicolumn{2}{|c|}{ End- Sept. } & \multicolumn{2}{|c|}{ Year } & & \\
\hline & & & & Prog. & $\overline{\text { Est. }}$ & Prog. & Rev. Proj. & Proj. & Budget \\
\hline Overall revenues and grants & 1,446 & 2,190 & 2,763 & 2,465 & 2,728 & 3,611 & 3,761 & 4,890 & 5,036 \\
\hline Total revenues & 1,393 & 1,754 & 2,621 & 2,313 & 2,642 & 3,343 & 3,589 & 4,603 & 4,749 \\
\hline Tax revenues & 1,196 & 1,533 & 2,274 & 2,098 & 2,424 & 2,979 & 3,218 & 4,189 & 4,251 \\
\hline Income and profit tax & 151 & 194 & 305 & 277 & 334 & 390 & 422 & 630 & 654 \\
\hline Payroll taxes & 154 & 189 & 253 & 228 & 247 & 319 & 340 & 465 & 472 \\
\hline Property taxes & 61 & 77 & 92 & 96 & 89 & 131 & 140 & 176 & 166 \\
\hline Taxes on goods and services & 675 & 902 & 1,398 & 1,306 & 1,534 & 1,861 & 2,000 & 2,524 & 2,611 \\
\hline VAT & 492 & 675 & 1,061 & 1,000 & 1,160 & 1,432 & 1,535 & 1,959 & 2,018 \\
\hline Excises and other internal indirect taxes & 183 & 227 & 337 & 308 & 374 & 428 & 466 & 565 & 593 \\
\hline International trade and operations tax & 155 & 171 & 226 & 134 & 149 & 278 & 317 & 394 & 349 \\
\hline Sales taxes & 55 & 87 & 95 & 64 & 61 & 102 & 107 & 133 & 102 \\
\hline Import duties & 99 & 84 & 131 & 127 & 159 & 176 & 210 & 261 & 247 \\
\hline Non-tax revenues & 197 & 221 & 347 & 215 & 218 & 364 & 371 & 414 & 498 \\
\hline Grants 1/ & 53 & 436 & 142 & 152 & 86 & 268 & 172 & 287 & 288 \\
\hline Of which: PIP financing & 0 & 59 & 107 & 152 & 86 & 194 & 172 & 210 & 210 \\
\hline Total expenditures and lending minus repayments & 1,655 & 2,032 & 3,555 & 3,281 & 3,505 & 4,898 & 5,019 & 6,432 & 6,093 \\
\hline Current expenditures & 1,088 & 1,393 & 1,740 & 1,631 & 1,631 & 2,488 & 2,498 & 3,451 & 3,451 \\
\hline Expenditures on goods and services & 752 & 967 & 1,197 & 2,748 & 1,074 & 1,761 & 1,716 & 2,564 & 2,564 \\
\hline Wages and salaries & 270 & 384 & 525 & 529 & 483 & 742 & 742 & 1,093 & 1,093 \\
\hline Others & 483 & 583 & 672 & 640 & 591 & 1,019 & 974 & 1,471 & 1,471 \\
\hline Interest payments & 36 & 46 & 59 & 57 & 45 & 91 & 91 & 107 & 107 \\
\hline Transfers and subsidies & 300 & 380 & 484 & 406 & 513 & 635 & 690 & 780 & 780 \\
\hline Transfers to households & 269 & 346 & 445 & 364 & 399 & 556 & 556 & 390 & 390 \\
\hline Subsidies and other current transfers & 31 & 34 & 39 & 43 & 114 & 79 & 134 & 390 & 390 \\
\hline Capital expenditures & 562 & 634 & 1,807 & 1,542 & 1,721 & 2,264 & 2,376 & 2,800 & 2,460 \\
\hline Externally financed PIP & 243 & 291 & 1,101 & 1,053 & 1,195 & 1,488 & 1,599 & 1,502 & 1,162 \\
\hline Of which: with loans from China & 0 & 0 & 747 & 1,053 & 1,195 & 840 & 956 & 683 & 378 \\
\hline Domestically financed & 318 & 342 & 707 & 489 & 526 & 777 & 777 & 1,298 & 1,298 \\
\hline Lending minus repayments $2 /$ & 5 & 6 & 8 & 108 & 153 & 146 & 146 & 181 & 181 \\
\hline Statistical discrepancy & 16 & 22 & 73 & -23 & 89 & $\ldots$ & $\cdots$ & $\ldots$ & $\cdots$ \\
\hline Overall balance (incl. PIP) & -209 & 158 & -791 & -816 & -777 & $-1,286$ & $-1,259$ & $-1,542$ & $-1,056$ \\
\hline Overall balance (excl. PIP and PIP related grants) $3 /$ & 35 & 70 & 202 & 85 & 332 & 8 & 169 & -250 & -104 \\
\hline Total financing (incl. PIP) & 209 & -158 & 791 & 816 & 777 & 1,286 & 1,259 & 1,542 & 1,056 \\
\hline Net external & 184 & 145 & 885 & 802 & 992 & 1,163 & 1,304 & 1,232 & 1,188 \\
\hline Disbursements & 261 & 269 & 993 & 901 & 1,108 & 1,313 & 1,427 & 1,309 & 1,292 \\
\hline Program loans & 18 & 37 & 0 & 0 & 0 & 19 & 0 & 18 & 0 \\
\hline Project loans & 243 & 232 & 993 & 901 & 1,108 & 1,294 & 1,427 & 1,292 & 1,292 \\
\hline Amortization & -77 & -124 & -108 & -99 & -117 & -150 & -123 & -77 & -104 \\
\hline Net domestic & 24 & -303 & -94 & 14 & -214 & 124 & -46 & 310 & -131 \\
\hline NBT & -18 & -379 & -136 & -19 & -248 & 86 & -6 & 281 & -160 \\
\hline Commercial banks & -9 & -3 & -47 & 39 & -71 & 13 & -60 & 14 & 14 \\
\hline Gross proceeds from privatization & 35 & 57 & 17 & 16 & 17 & 25 & 20 & 15 & 15 \\
\hline \multicolumn{10}{|l|}{ Memorandum items: } \\
\hline Total public and publicly-guaranteed debt (in millions of U.S. dollars) & 954 & 964 & 1,283 & $\ldots$ & $\ldots$ & 1,548 & 1,606 & 2,104 & \\
\hline
\end{tabular}

1/ 2006 grants figure includes the MDRI debt relief of 3.5 percent of GDP.

2/ Includes SM140 mn lending to the cotton sector in 2008, and SM170 mn for 2009

$3 / 2006$ overall balance excludes the MDRI debt relief that is reflected in grants. 
Table 4. Tajikistan: Accounts of the National Bank of Tajikistan, 2004-09

(End-of-period stock; unless otherwise specified)

\begin{tabular}{|c|c|c|c|c|c|c|c|c|c|}
\hline & \multirow{3}{*}{$\begin{array}{l}2005 \\
\text { Dec. } \\
\text { Act. }\end{array}$} & \multirow{3}{*}{$\begin{array}{l}2006 \\
\text { Dec. } \\
\text { Act. }\end{array}$} & \multirow{3}{*}{$\begin{array}{l}2007 \\
\text { Dec. } \\
\text { Act. }\end{array}$} & \multicolumn{5}{|c|}{2008} & \multirow{3}{*}{$\begin{array}{l}2009 \\
\text { Dec. } \\
\text { proj. }\end{array}$} \\
\hline & & & & \multirow{2}{*}{$\begin{array}{c}\text { June } \\
\text { Act. }\end{array}$} & \multicolumn{2}{|c|}{ Sept. } & \multicolumn{2}{|c|}{ Dec. } & \\
\hline & & & & & $\begin{array}{c}\text { Adj. } \\
\text { prog. 1/ }\end{array}$ & Act. & $\begin{array}{c}\text { Adj. } \\
\text { prog. 1/ }\end{array}$ & proj. & \\
\hline & \multicolumn{9}{|c|}{ (In millions of somoni) } \\
\hline Net foreign assets & 308 & 673 & 907 & 1,027 & 595 & 770 & 402 & 420 & 409 \\
\hline Gross assets & 718 & 860 & 1,205 & 1,308 & 1,374 & 1,023 & 1,409 & 594 & 539 \\
\hline Gross liabilities & 410 & 201 & 306 & 284 & 267 & 261 & 184 & 178 & 122 \\
\hline of which: Net international reserves & 308 & 707 & 1,030 & 1,138 & 1,229 & 879 & 1,347 & 530 & 525 \\
\hline Gross reserves & 718 & 860 & 1,205 & 1,308 & 1,374 & 1,023 & 1,409 & 594 & 539 \\
\hline Gross short-term liabilities & 410 & 153 & 175 & 170 & 145 & 143 & 62 & 64 & 14 \\
\hline Net domestic assets 1/ & 376 & 348 & 525 & 419 & 1,039 & 864 & 1,371 & 1,403 & 1,829 \\
\hline Net credit to general government & -220 & -636 & -774 & $-1,012$ & -737 & $-1,019$ & -687 & -777 & -495 \\
\hline Credit to the private sector & 565 & 932 & 1,162 & 1,248 & 1,187 & 1,684 & 1,186 & 1,979 & 2,124 \\
\hline Claims on banks & 411 & 749 & 982 & 1,046 & 1,025 & 1,489 & 999 & 1,786 & 1,932 \\
\hline Of which : Cotton sector 1/ & 378 & 571 & 885 & 1,007 & 893 & 1,442 & 893 & 1,753 & 1,753 \\
\hline Of which: NBT bills & -27 & -4 & -10 & -41 & -31 & -36 & -58 & -50 & 95 \\
\hline Credit to non-bank institutions & 155 & 183 & 180 & 202 & 130 & 194 & 129 & 193 & 192 \\
\hline Other items, net & 31 & 52 & 137 & 183 & 47 & 200 & -5 & 200 & 200 \\
\hline Of which: Undivided profits (+ losses) & 16 & -15 & 12 & 727 & 0 & 1,006 & $\cdots$ & $\ldots$ & $\ldots$ \\
\hline Reserve money & 684 & 1,021 & 1,432 & 1,446 & 1,635 & 1,634 & 1,776 & 1,823 & 2,237 \\
\hline Currency in circulation & 581 & 883 & 1,123 & 1,229 & 1,307 & 1,443 & 1,415 & 1,505 & 1,754 \\
\hline Bank reserves & 100 & 134 & 249 & 206 & 296 & 191 & 329 & 317 & 483 \\
\hline Required reserves & 64 & 66 & 139 & 182 & 219 & 173 & 236 & 231 & 331 \\
\hline \multirow[t]{2}{*}{ Other bank deposits } & 36 & 68 & 109 & 24 & 78 & 18 & 93 & 86 & 152 \\
\hline & \multicolumn{9}{|c|}{ (In millons of U.S. dollars at program exchange rate) 2/ } \\
\hline Net foreign assets & $\ldots$ & $\ldots$ & $\ldots$ & 306 & 322 & 240 & 357 & 138 & $\ldots$ \\
\hline of which: Net international reserves & $\ldots$ & $\ldots$ & $\ldots$ & 122 & 117 & 181 & 151 & 170 & $\ldots$ \\
\hline \multirow[t]{2}{*}{ Net domestic assets } & $\ldots$ & $\ldots$ & $\ldots$ & 115 & 304 & 236 & 401 & 392 & $\ldots$ \\
\hline & \multicolumn{9}{|c|}{ (12-month growth in percent of reserve money) } \\
\hline Reserve money & 29.2 & 49.2 & 40.3 & 37.7 & 16.2 & 16.1 & 24.1 & 27.3 & 22.7 \\
\hline Net foreign assets & 19.4 & 53.4 & 22.9 & 30.7 & 11.2 & 1.6 & 20.5 & -34.0 & -0.6 \\
\hline Of which: gross international reserves & 26.9 & 20.8 & 33.8 & 36.6 & 16.3 & -8.6 & 14.2 & -42.7 & -3.0 \\
\hline Of which: net international reserves & 19.4 & 58.4 & 31.6 & 35.2 & 11.1 & -7.5 & 16.4 & -34.9 & -0.3 \\
\hline Net domestic assets & 9.8 & -4.2 & 17.4 & 8.3 & 5.0 & 25.3 & 3.6 & 61.2 & 23.4 \\
\hline \multicolumn{10}{|l|}{ Of which: } \\
\hline Net credit to general government & -4.9 & -60.8 & -13.5 & -18.2 & 7.4 & -12.6 & 6.1 & -0.2 & 15.4 \\
\hline Credit to the private sector & 15.3 & 53.6 & 22.5 & 17.6 & -1.5 & 34.4 & 1.0 & 57.1 & 7.9 \\
\hline Of which: NBT bills & -4.1 & 3.3 & -0.6 & -3.6 & 0.0 & -1.9 & 0.0 & -2.8 & 8.0 \\
\hline Other items net & -0.6 & 3.1 & 8.4 & 8.8 & -7.3 & 3.5 & -10.0 & 4.4 & 0.0 \\
\hline \multicolumn{10}{|l|}{ Memorandum items: } \\
\hline Net international reserves (in millions of U.S.dollars) & -37 & 67 & 56 & 115 & 117 & 167 & 151 & 156 & 146 \\
\hline Net international reserves (percent of broad money) & -12.7 & 14.9 & 7.1 & 15.3 & 12.7 & 20.9 & 15.2 & 14.6 & 11.6 \\
\hline Pledged international reserves (in millions of U.S. dollars) & 133 & 140 & 241 & 216 & 241 & 91 & 241 & 0 & 0 \\
\hline Official exchange rate (somoni/U.S. dollars) & 3.199 & 3.427 & 3.465 & 3.431 & 3.435 & 3.409 & 3.435 & $\ldots$ & $\ldots$ \\
\hline
\end{tabular}

Sources: National Bank of Tajikistan; and Fund staff estimates.

$1 /$ In June, September and October the program ceiling on net domestic assets of the National Bank of Tajikistan was adjusted upwards to reflect the retention of the pledged deposits.

2/ Based on accounting exchange rates: somoni 3.435=1 U.S. dollar, 1 SDR = 1.65 U.S. dollar, and gold price of 978.3 U.S. dollar per troy ounce (end-March 2008 rates) 
Table 5. Tajikistan: Monetary Survey, 2004-09

\begin{tabular}{|c|c|c|c|c|c|c|c|c|c|}
\hline & \multirow{3}{*}{$\begin{array}{l}2005 \\
\text { Dec. } \\
\text { Act. }\end{array}$} & \multirow{3}{*}{$\begin{array}{l}2006 \\
\text { Dec. } \\
\text { Act. }\end{array}$} & \multirow{3}{*}{$\begin{array}{l}2007 \\
\text { Dec. } \\
\text { Act. }\end{array}$} & \multicolumn{5}{|c|}{2008} & \multirow{3}{*}{$\begin{array}{l}2009 \\
\text { Dec. } \\
\text { Proj. }\end{array}$} \\
\hline & & & & \multirow{2}{*}{$\begin{array}{c}\text { June } \\
\text { Act. }\end{array}$} & \multicolumn{2}{|c|}{ Sept. } & \multicolumn{2}{|c|}{ Dec. } & \\
\hline & & & & & $\begin{array}{l}\text { Adj. } \\
\text { prog. }\end{array}$ & Act. & $\begin{array}{l}\text { Adj. } \\
\text { prog. }\end{array}$ & Proj. & \\
\hline & \multicolumn{9}{|c|}{ (In millions of somoni, end-of-period stock; unless otherwise specified) 1/ } \\
\hline Net foreign assets & -250 & -15 & 59 & -169 & -314 & -140 & -528 & -509 & -528 \\
\hline National Bank of Tajikistan & 308 & 673 & 907 & 1027 & 595 & 770 & 402 & 420 & 409 \\
\hline Commercial banks & -557 & -688 & -849 & -1196 & -909 & -910 & -930 & -930 & -937 \\
\hline Net domestic assets & 1,196 & 1,553 & 2,697 & 2,779 & 2,977 & 2,867 & 3,131 & 4,162 & 5,073 \\
\hline Net credit to general government & -255 & -674 & -859 & $-1,149$ & -831 & $-1,176$ & -759 & -922 & -627 \\
\hline Credit to the private sector & 1,604 & 2,390 & 3,794 & 4,341 & 4,118 & 4,484 & 4,204 & 5,530 & 6,146 \\
\hline Other items, net & -153 & -163 & -238 & -413 & -309 & -441 & -314 & -446 & -446 \\
\hline Broad money & 937 & 1,530 & 2,736 & 2,586 & 3,163 & 2,715 & 3,413 & 3,641 & 4,530 \\
\hline Somoni broad money & 674 & 1,046 & 1,447 & 1,495 & 1,538 & 1,703 & 1,660 & 2,284 & 2,842 \\
\hline Currency outside banks & 534 & 825 & 1,037 & 1,064 & 1,055 & 1,263 & 1,138 & 1,693 & 1,923 \\
\hline Deposits & 140 & 220 & 410 & 432 & 483 & 440 & 521 & 591 & 919 \\
\hline Foreign currency deposits & 263 & 485 & 1,289 & 1,091 & 1,625 & 1,012 & 1,753 & 1,357 & 1,688 \\
\hline \multirow[t]{2}{*}{ Bill payable 1/ } & 10 & 8 & 19 & 23 & 12 & 12 & 12 & 12 & 15 \\
\hline & \multicolumn{9}{|c|}{ (12 month growth in percent of broad money) } \\
\hline Broad money & 30.2 & 63.4 & 78.8 & 53.2 & 50.4 & 29.2 & 24.7 & 33.0 & 24.4 \\
\hline Net foreign assets & -70.3 & 25.1 & 4.8 & 2.9 & 15.3 & 1.6 & 7.7 & -20.8 & -0.5 \\
\hline National Bank of Tajikistan & 14.3 & 39.0 & 15.3 & 18.3 & -14.5 & -6.2 & -18.5 & -17.8 & -0.3 \\
\hline Commercial banks & -84.5 & -13.9 & -10.5 & -15.4 & 7.8 & 7.8 & -3.0 & -3.0 & -0.2 \\
\hline Net domestic assets & 100.4 & 38.2 & 74.7 & 50.9 & 34.9 & 27.5 & 16.8 & 53.5 & 25.0 \\
\hline Net credit to general government & -4.9 & -44.7 & -12.1 & -15.6 & 4.6 & -11.8 & 3.6 & -2.3 & 8.1 \\
\hline Credit to the private sector & 56.2 & 84.0 & 91.7 & 84.6 & 36.5 & 54.3 & 15.0 & 63.4 & 16.9 \\
\hline Other items, net & 49.1 & -1.1 & -4.9 & -18.1 & -8.8 & -15.0 & -2.8 & -7.6 & 0.0 \\
\hline Bill payable & 0.0 & -0.1 & 0.7 & 0.6 & -0.1 & -0.2 & -0.2 & -0.3 & 0.1 \\
\hline \multicolumn{10}{|l|}{ Memorandum items: } \\
\hline Credit to the private sector (12-month percent change) & 33.7 & 49.1 & 58.7 & 49.1 & 22.9 & 34.2 & 10.8 & 45.7 & 11.1 \\
\hline Velocity & 7.7 & 6.1 & 4.7 & & & & 4.7 & 4.7 & 4.7 \\
\hline Money multiplier 2/ & 1.4 & 1.5 & 1.9 & 1.8 & 1.9 & 1.7 & 1.9 & 2.0 & 2.0 \\
\hline
\end{tabular}

Sources: National Bank of Tajikistan; and Fund staff estimates.

$1 /$ Liabilities to cotton financiers related to domestic cotton financing.

2/ Broad money divided by reserve money. 
Table 6. Tajikistan: Balance of Payments, 2005-13 (In millions of U.S. dollars)

\begin{tabular}{|c|c|c|c|c|c|c|c|c|c|c|}
\hline & \multirow{2}{*}{$\begin{array}{r}2005 \\
\text { Act. }\end{array}$} & \multirow{2}{*}{$\begin{array}{r}2006 \\
\text { Act. }\end{array}$} & \multirow{2}{*}{$\begin{array}{r}2007 \\
\text { Est. }\end{array}$} & \multicolumn{2}{|c|}{2008} & \multirow{2}{*}{$\begin{array}{c}2009 \\
\text { Proj. }\end{array}$} & \multirow{2}{*}{$\begin{array}{c}2010 \\
\text { Proj. }\end{array}$} & \multirow{2}{*}{$\begin{array}{c}2011 \\
\text { Proj. }\end{array}$} & \multirow{2}{*}{$\begin{array}{c}2012 \\
\text { Proj. }\end{array}$} & \multirow{2}{*}{$\begin{array}{r}2013 \\
\text { Proj. }\end{array}$} \\
\hline & & & & Prog. & Proj. & & & & & \\
\hline Current account & -62 & -79 & -414 & -429 & -466 & -538 & -483 & -529 & -698 & -792 \\
\hline Balance on goods and services $1 /$ & -620 & -961 & $-1,788$ & $-2,333$ & $-2,747$ & $-2,820$ & $-2,953$ & $-3,228$ & $-3,529$ & $-3,781$ \\
\hline Balance on goods & -622 & -986 & $-1,673$ & $-2,187$ & $-2,534$ & $-2,619$ & $-2,779$ & $-2,990$ & $-3,255$ & $-3,475$ \\
\hline Exports & 346 & 350 & 385 & 402 & 424 & 433 & 452 & 486 & 511 & 542 \\
\hline Imports & -968 & $-1,336$ & $-2,058$ & $-2,589$ & $-2,959$ & $-3,051$ & $-3,231$ & $-3,475$ & $-3,766$ & $-4,018$ \\
\hline Balance on services & 2 & 25 & -115 & -146 & -213 & -202 & -174 & -239 & -273 & -305 \\
\hline Balance on income & -79 & -101 & -111 & -120 & -116 & -121 & -123 & -131 & -133 & -141 \\
\hline Balance on transfers & 636 & 984 & 1,484 & 2,024 & 2,397 & 2,403 & 2,593 & 2,830 & 2,963 & 3,129 \\
\hline Of which: migrants' remittances, net & 526 & 903 & 1,416 & 1,957 & 2,315 & 2,315 & 2,518 & 2,765 & 2,906 & 3,083 \\
\hline Capital and financial account & 73 & 183 & 409 & 520 & 588 & 543 & 483 & 529 & 698 & 792 \\
\hline Capital transfers & 19 & 127 & 31 & 52 & 50 & 60 & 60 & 60 & 37 & 42 \\
\hline Public sector (net) & 48 & 45 & 273 & 301 & 374 & 336 & 191 & 114 & 294 & 362 \\
\hline Disbursements & 86 & 82 & 308 & 350 & 417 & 369 & 223 & 172 & 367 & 424 \\
\hline Of which: projects financed by China & $\ldots$ & $\ldots$ & 217 & 224 & 279 & 195 & $\cdots$ & $\ldots$ & $\ldots$ & $\ldots$ \\
\hline Amortization & -38 & -37 & -35 & -44 & -42 & -33 & -32 & -59 & -72 & -62 \\
\hline FDI & 55 & 66 & 160 & 180 & 190 & 100 & 160 & 180 & 210 & 235 \\
\hline Commercial bank NFA (- increase) & 191 & 27 & 44 & 1 & 28 & -13 & -17 & -12 & -10 & -8 \\
\hline NBT pledged deposits & -14 & -6 & -102 & 0 & 241 & $\ldots$ & $\ldots$ & $\ldots$ & $\ldots$ & .. \\
\hline Other short-term capital and errors and omissions $2 / 3 /$ & -225 & -75 & 2 & -14 & -296 & 60 & 69 & 187 & 168 & 161 \\
\hline Overall balance & 11 & 104 & -5 & 92 & 122 & 5 & 0 & 0 & 0 & 0 \\
\hline Financing items & -11 & -104 & 5 & -92 & -122 & -5 & 0 & 0 & 0 & 0 \\
\hline Use of international reserves (- increase) & -27 & -20 & 5 & -62 & -91 & 10 & 0 & 0 & 0 & 0 \\
\hline IMF (net) & 15 & -85 & 0 & -29 & -31 & -15 & 0 & 0 & 0 & 0 \\
\hline Purchases/disbursements & 29 & 14 & 0 & 0 & 0 & 0 & 0 & 0 & 0 & 0 \\
\hline Repurchases/repayments & 14 & 99 & 0 & 29 & 31 & 15 & 0 & 0 & 0 & 0 \\
\hline \multicolumn{11}{|l|}{ Memorandum items: } \\
\hline Nominal GDP & 2,311 & 2,811 & 3,712 & 4,300 & 5,014 & 6,107 & 6,893 & 7,951 & 9,174 & 10,594 \\
\hline Current account balance (in percent of GDP) & -2.7 & -2.8 & -11.2 & -10.0 & -9.3 & -8.8 & -7.0 & -6.7 & -7.6 & -7.5 \\
\hline Gross reserves & 91 & 111 & 107 & 169 & 198 & 188 & 188 & 188 & 188 & 188 \\
\hline (in months of next year's imports) 4/ & 0.9 & 0.7 & 0.5 & 0.8 & 0.8 & 0.7 & 0.7 & 0.6 & 0.6 & 0.5 \\
\hline Total Public and Publicly Guaranteed (PPG) external sector debt & 897 & 910 & 1,232 & 1,492 & 1,556 & 1,859 & 2,058 & 2,167 & 2,432 & 2,754 \\
\hline (in percent of GDP) & 38.8 & 32.4 & 33.2 & 34.7 & 31.0 & 30.4 & 29.8 & 27.3 & 26.5 & 26.0 \\
\hline Debt service on PPG external debt 5/ & 60 & 49 & 49 & 111 & 112 & 81 & 68 & 98 & 108 & 99 \\
\hline (in percent of exports of goods) & 17.5 & 14.0 & 12.8 & 27.7 & 26.4 & 18.8 & 15.1 & 20.1 & 21.2 & 18.2 \\
\hline
\end{tabular}

Sources: Tajik authorities; and Fund staff estimates.

$1 /$ Starting from 2005, the export and import figures reflect the transition to the tolling arrangement for aluminium exports. $2 /$ Includes accumulation of foreign currency balances by residents of Tajikistan.

3/ For 2008, includes the decline in other foreign liabilities which resulted from pledged deposits settlement. 4/ Excluding electricity, which is on barter basis, and imports related to projects financed with loans from China. 5/ Data for 2006 exclude $\$ 99$ million IMF repurchase under MDRI assistance. 


\section{ATTACHMENT I. LETTER OF INTENT}

November 26, 2008

His Excellency

Mr. Dominique Strauss-Kahn

Managing Director

International Monetary Fund

$70019^{\text {th }}$ Street, N.W.

Washington, DC 20431

Dear Mr. Strauss-Kahn:

Using the opportunity I would like to express my gratitude to the International Monetary Fund for its continued support of our economic reforms, including through the ongoing staff monitored program (SMP). We are currently taking the necessary measures to address the problems associated with the episode of misreporting that was exposed late last year, and to remove the institutional weaknesses that led to it. The field work for the special audit of the National Bank of Tajikistan (NBT) has been completed and the draft report will be made available to the NBT in late November of this year. We also made three repayments to the IMF through November, and expect to make the remaining three monthly payments as scheduled.

It is heartening that macroeconomic developments through end-September 2008 were positive, despite last winter's difficulties and the drought and locust problems during the recent crop season. Economic growth was stronger than envisaged under the SMP. This was partly driven by a surge in remittances, which allowed the NBT to accumulate net international reserves faster than programmed. We were able to achieve an overall fiscal surplus (excluding the externally financed public investment program, PIP), higher than targeted, largely because of buoyant revenues. At the same time, concessional loan disbursements under the PIP at end-September were faster than anticipated, though all disbursements were made under existing loan agreements and do not constitute additional borrowing. As a result of these disbursements, we now project a higher amount of concessional external borrowing at end-December than programmed. In this context, the government, on October 28, 2008, approved a three year debt management strategy that sets a debt ceiling of 40 percent of GDP. We also tendered the audit of the state-owned aluminum smelter Talco and the state-owned electricity company Barki Tajik, and issued a decree establishing a supervision unit in the Ministry of Finance for regular monitoring of the financial operations of the 10 largest state-owned enterprises. Despite our efforts, Barki Tajik's tax arrears increased, mostly due to the non-payment by water users in the agricultural sector. In this regard, we are working on a plan to significantly reduce tax arrears, including through higher penalties for all categories of tax arrears, and the implementation of an effective mechanism of arrears repayment by water users. 
We are confident that we will achieve our SMP policy objectives for end-December 2008. In this context, we remain committed to the policies and targets I set out in my letter dated June 10, 2008. During the last quarter of 2008, we expect to strengthen our net international reserves position somewhat faster than previously projected, and intend to save any revenue overperformance while maintaining strict expenditure control.

${ }^{1}$ However, it will take more time than initially thought to finalize the amendments to the NBT Law of the Republic of Tajikistan and the Commercial Banking Law of the Republic of Tajikistan. We have prepared a first draft of these amendments which go beyond the scope of the program, incorporating additional recommendations from the Financial Sector Stability Assessment (FSSA) report, and which we will now discuss with Fund staff. We plan to submit these amendments to the national parliament by March 2009. ${ }^{2}$

It is of note that the external environment will weigh on Tajikistan's macroeconomic outlook in 2009. The projected global slowdown, in particular in Russia and Kazakhstan, may affect remittances and thus dampen domestic demand. In addition, cotton and aluminum exports are likely to be adversely affected by a reduction in external demand and declining international prices. However, with little direct linkages to global financial markets, we do not foresee any direct impact on Tajikistan's financial sector. All in all, we still aim to sustain the same growth level as in 2008. At the same time, with global food and fuel prices subsiding, we see inflation slowing throughout the year.

In this difficult global context, macroeconomic policies will be geared toward maintaining stability, while structural reforms will aim at raising Tajikistan's medium-term growth potential. The 2009 budget targets a modest overall fiscal deficit (excluding the PIP) of $1 / 2$ percent of GDP, allowing us to raise social spending by over 60 percent and undertake important investments in hydropower and other infrastructure. We see only little scope for a further build-up of reserves in 2009, and will allow the exchange rate to move in line with market trends.

Negotiations with foreign creditors over guarantees issued by the NBT are currently ongoing, and we are committed to settling all valid claims promptly while maximizing loan recoveries from domestic investors. Our structural reform agenda for 2009 will focus, inter alia, on: improving the financial position and governance of the NBT, enhancing transparency and management at key state-owned enterprises, strengthening tax administration and public financial management, creating an environment for financial sector development, and resolving the domestic cotton debt problem.

\footnotetext{
${ }^{1}$ See Table 1.

${ }^{2}$ See Table 2.
} 
In line with our commitment to transparency of economic policies, we will continue publishing all SMP-related documents on the IMF's website as well as the recent FSSA report. In addition, we will publish all key findings of the special audit of the NBT on the NBT's website.

Given the good progress we have made so far under the SMP and our firm commitment to successfully completing our 2008 program, we hope to begin discussions on a new program that could be supported by the Fund under the Poverty Reduction and Growth Facility in early 2009.

Your Excellency, please accept my assurances of my highest consideration,

/s/

Emomali Rakhmon

President of the Republic of Tajikistan 
Table 1. Tajikistan: Quantitative Indicators under the 2008 Staff Monitored Program

(In millions of somoni, unless otherwise indicated)

\begin{tabular}{|c|c|c|c|c|c|c|c|c|}
\hline & \multicolumn{8}{|c|}{2008} \\
\hline & \multicolumn{3}{|c|}{ End-June } & \multicolumn{3}{|c|}{ End-Sept. } & \multicolumn{2}{|c|}{ End-Dec. } \\
\hline & Prog. & Adj. Prog. & Est. & Prog. & Adj. Prog. & Est. & Prog. & Rev. Prog. \\
\hline \multicolumn{9}{|l|}{ Indicative Targets: } \\
\hline 1. Ceiling on net domestic assets of the NBT $1 / 2$ / & 454 & 540 & 394 & 528 & 1,043 & 809 & 551 & 551 \\
\hline 2. Ceiling on net credit of the banking system to general government & -953 & -953 & $-1,149$ & -831 & -831 & $-1,178$ & -759 & -759 \\
\hline 3. Floor on total net international reserves (in millions of U.S. dollars) 2/ & 96 & 96 & 122 & 117 & 117 & 181 & 151 & 170 \\
\hline $\begin{array}{l}\text { 4. Floor on the cumulative overall fiscal balance of the general } \\
\text { government (excluding foreign-financed public investment program and } \\
\text { PIP related grants) } 3 /\end{array}$ & 148 & 148 & 310 & 62 & 62 & 331 & 8 & 8 \\
\hline $\begin{array}{l}\text { 5. Ceiling on general government wage, and nonworking } \\
\text { pensioners' pension arrears } 4 /\end{array}$ & 0 & 0 & 0 & 0 & 0 & & 0 & 0 \\
\hline 6. Floor on tax collection $3 /$ & 1,502 & 1,502 & 1,572 & 2,277 & 2,277 & 2,423 & 2,979 & 2,979 \\
\hline 7. New tax arrears of Barki Tajik and Talco & 0 & 0 & 7 & 0 & 0 & 22 & 0 & 0 \\
\hline 8. Ceiling on contracting or guaranteeing of any nonconcessional external debt $4 / 5 / 6$ / & 0 & 0 & 0 & 0 & 0 & 0 & 0 & 0 \\
\hline $\begin{array}{l}\text { 9. Ceiling on disbursements of concessional external financing } \\
\text { (in millions of U.S. dollars) } 3 / 5 / 6 /\end{array}$ & 206 & 206 & 156 & 283 & 283 & 323 & 350 & 413 \\
\hline 10. New external payments arrears $4 /$ & 0 & 0 & 0 & 0 & 0 & 0 & 0 & 0 \\
\hline \multicolumn{9}{|l|}{ Memorandum item: } \\
\hline $\begin{array}{l}\text { Cumulative disbursement of program loans and grants } 3 \text { / } \\
\text { (in millions of U.S. dollars) }\end{array}$ & 0 & 0 & 0 & 0 & 0 & 0 & 25 & 25 \\
\hline
\end{tabular}

1/ In June, September and December the program ceiling on NDA of the NBT was adjusted upwards to reflect the retention of the pledged deposits.

2/ At program exchange rates.

$3 /$ Cumulative from January 1of the year.

4/ Continuous quantitative targets.

5/ Short, medium and long-term debt by the government, NBT or any other agency acting on behalf of the government

as defined in the Technical Memorandum of Understanding, excluding normal trade-related loans.

$6 /$ Excluding the obligations resulting from the restructuring of the cotton debt. 
Table 2. Prior Actions and Structural Benchmarks under the 2008 Staff-Monitored Program

\begin{tabular}{|c|c|c|}
\hline Areas of Reform & Implementation Date & Status \\
\hline $\begin{array}{l}\text { 1. Reach understandings with Fund staff on the Terms of Reference for the special } \\
\text { audit of the NBT and other involved parties, as defined in the terms of reference. }\end{array}$ & Prior action & $\begin{array}{l}\text { Completed } \\
\text { Apr. } 2008\end{array}$ \\
\hline $\begin{array}{l}\text { 2. Request bids for the selection of an internationally reputable audit firm to conduct } \\
\text { the special audit of the NBT and other involved parities defined in the terms of } \\
\text { reference. }\end{array}$ & Prior action & $\begin{array}{l}\text { Completed } \\
\text { May } 2008\end{array}$ \\
\hline $\begin{array}{l}\text { 3. Provide interim reports, as noted in the terms of reference of the special audit of } \\
\text { the NBT, to Fund staff. }\end{array}$ & Monthly & Complied with \\
\hline $\begin{array}{l}\text { 4. NBT will refrain from issuing new credits to the private sector, except to } \\
\text { commercial banks (including Amonatbank) for liquidity and lender of last resort } \\
\text { purposes. These involve credits that are issued in the absence of a competitive } \\
\text { auction or on non-market terms and conditions. }\end{array}$ & Continuous & Complied with \\
\hline $\begin{array}{l}\text { 5. Make legislative changes to: (i) appoint the NBT chairman and his deputies for } \\
\text { fixed terms that do not coincide with the electoral cycle, and outline the reasons for } \\
\text { their dismissal explicitly in the law; (ii) require official identification and disclosure of } \\
\text { beneficial owners of companies registered with the Agency for Securities in the } \\
\text { Ministry of Finance and other authorized entities, including financial institutions; (iii) } \\
\text { clarify the provisions covering conflicts of interest for the NBT management and } \\
\text { staff and require them to disclose their personal holdings in financial institutions and } \\
\text { excuse themselves from official decisions affecting those institutions. }\end{array}$ & End-Dec. 2008 & $\begin{array}{l}\text { Expected to } \\
\text { be delayed } \\
\text { until March } 2009\end{array}$ \\
\hline $\begin{array}{l}\text { 6. Issue tender papers for an audit of Talco's and Barki Tajik's } 2007 \text { financial } \\
\text { operations by an internationally recognized auditing company. }\end{array}$ & End-Sept. 2008 & $\begin{array}{l}\text { Completed } \\
\text { Sept. } 2008\end{array}$ \\
\hline \multicolumn{3}{|l|}{$\begin{array}{l}\text { 7. Introduce legislative changes for establishing a contingent liability reporting } \\
\text { regime to cover state-owned enterprises, public institutions and the NBT. }\end{array}$} \\
\hline $\begin{array}{l}\text { 8. Issue a government decree to establish a supervision unit in the Ministry of } \\
\text { Finance (MoF) for regular monitoring of financial operations of the } 10 \mathrm{SOE} \text { 's with the } \\
\text { highest annual turnover and require these enterprises to provide the MoF and } \\
\text { Ministry of Economic Development and Trade draft annual financial plans for review } \\
\text { and approval before the beginning of each financial year and submit their quarterly } \\
\text { financial statements and their external audit reports. }\end{array}$ & End-Sept.-2008 & $\begin{array}{l}\text { Completed } \\
\text { Sept. } 2008\end{array}$ \\
\hline
\end{tabular}




\section{INTERNATIONAL MONETARY FUND}

TAJIKISTAN

First Assessment Under the Staff-Monitored Program-Informational Annex

December 10, 2008

Contents

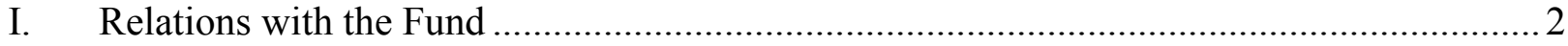

II. Relations with the World Bank ......................................................................... 5

III. Relations with the Asian Development Bank ...................................................... 13

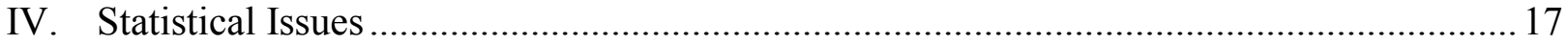




\section{ANNEX I. TAJIKISTAN: RELATIONS WITH THE FUND}

(As of October 31, 2008)

I. Membership Status: Joined April 27, 1993; Article VIII

\section{General Resources Account:}

Quota

$\begin{array}{rrr}\text { SDR million } & & \text { \% Quota } \\ 87.00 & & 100.00 \\ 87.00 & 100.00 \\ 0.00 & 0.00\end{array}$

III. SDR Department

Holdings

$\underline{\text { SDR million }}$

\% Allocation

19.85

N/A

IV. Outstanding Purchases and Loans

PRGF arrangements

$\frac{\text { SDR million }}{19.60} \quad \frac{\text { \% Quota }}{22.53}$

\section{Latest Financial Arrangements}

\begin{tabular}{lllccc} 
Type & \multicolumn{1}{c}{$\begin{array}{c}\text { Approval } \\
\text { Date }\end{array}$} & $\begin{array}{c}\text { Expiration } \\
\text { Date }\end{array}$ & $\begin{array}{c}\text { Amount Approved } \\
\text { (SDR million) }\end{array}$ & $\begin{array}{c}\text { Amount Drawn } \\
\text { (SDR million) }\end{array}$ \\
\cline { 1 - 3 } PRGF & Dec 11, 2002 & Feb 10, 2006 & 65.00 & 65.00 \\
ESAF/PRGF & Jun 24, 1998 & Dec 24, 2001 & 100.30 & 78.28 \\
Stand-by & May 08, 1996 & Dec 07, 1996 & 15.00 & 15.00
\end{tabular}

VI. Projected Payments to Fund

(SDR million; based on existing use of resources and present holdings of SDRs):

\begin{tabular}{lrrcrr} 
& \multicolumn{5}{c}{ Forthcoming } \\
\cline { 2 - 6 } & 2008 & 2009 & 2010 & 2011 & 2012 \\
Principal & 9.8 & 9.80 & & & \\
Charges/Interest & 0.04 & 0.00 & & & \\
Total & 9.84 & 9.80 & &
\end{tabular}

\section{Implementation of HIPC Initiative}

Not Applicable. 


\section{Implementation of MDRI Assistance}
I. Total Debt Relief (SDR Million) 69.31
Of Which MDRI $\quad 69.31$
HIPC

Eligible Debt

\begin{tabular}{llll}
\hline Delivery Date & $\underline{\text { GRA }}$ & $\underline{\text { PRGF }}$ & $\underline{\text { Total }}$ \\
January 2006 & N/A & 69.31 & 69.31
\end{tabular}

\section{Safeguards Assessment}

The previous safeguards assessment of the NBT was completed on July 23, 2003, which proposed specific measures to address a number of weaknesses, as reported in IMF Country Report $03 / 222$. The next safeguards assessment is pending the results of the special audit of the NBT.

\section{Exchange Rate Arrangements}

The NBT maintains conventional peg exchange rate arrangement, as per 2008 reclassification of the regime from managed float. Since August 2005, the NBT has increased the frequency of calculating and announcing the official exchange rate from a weekly to a daily basis. The official exchange rate is based on all interbank transactions in foreign exchange.

With effect from December 9, 2004, the Republic of Tajikistan accepted the obligations of Article VIII, Sections 2, 3, and 4 of the Articles of Agreement. As a result, the Republic of Tajikistan maintains an exchange system that is free of restrictions on the making of payments and transfers for current international transactions, except for exchange restrictions maintained for security reasons that have been notified to the Fund pursuant to Executive Board decision No. 144-(52/51).

\section{FSAP Participation}

Tajikistan participated in the Financial Sector Assessment Program during 2007-08, and the authorities have agreed to publish the FSSA report.

\section{Article IV Consultation}

The 2006 Article IV consultation was completed on March 28, 2007.

\section{Resident Representative}

Mr. Moers, Resident Representative of the Fund, started his assignment in Dushanbe in June 2006. 


\section{Technical Assistance}

The following list summarizes the technical assistance provided by the Fund to Tajikistan since 2002.

\section{Fiscal Affairs:}

July 2004

Revenue Administration Reform

December 2004

Poverty and Social Impact Analysis

June 2005

Public Financial Management

August 2005

Tax Policy and Administration

August 2006

Fiscal ROSC

May 2007

Public Financial Management (Budget Classification)

Monetary and Financial Systems:

July 2002

May 2006

Statistics:

October/November 2002

January 2003

February 2003

May 2003

April 2004

October 2004

June 2006

\section{Finance:}

May 2003

\section{Legal:}

March 2003

January 2004

May 2004
Multi-topic

Strengthening the Monetary Policy Framework and Liquidity Management

Money and Banking Statistics

Balance of Payments Statistics

Money and Banking Statistics

Balance of Payments Statistics

Data ROSC

General Data Dissemination System (GDDS)

Report on Monetary and Financial Statistics

Safeguards Assessment Follow-up

Tax Legislation

Tax Legislation

Tax Legislation 


\section{ANNEX II. TAJIKISTAN: RELATIONS WITH THE WORLD BANK}

(As of October 14, 2008)

Country Director: Ms. Annette Dixon

Telephone: (202) 4737089

Country Economist: Mr. Sudharshan Canagarajah

Telephone: (202) 4734458

\section{A. Partnership in Tajikistan's Development Strategy}

1. The Bank's Country Partnership Strategy, endorsed by the Bank's Board of Executive Directors on July 26, 2005, and updated on June 22 , 2007, focuses on the following three priorities, which are in line with the country's Second Poverty Reduction Strategy (PRS 2) for 2007-2009:

- $\quad$ To improve business opportunities in rural and urban areas.

- To enhance and preserve the quality of the human capital.

- $\quad$ To improve energy service delivery and increase electricity exports.

2. In addition, in each of the above areas, the Bank Group and government have agreed to work to improve government capacity for service delivery, and to reduce corruption by giving special emphasis to measures that increase transparency of resource use, reduce discretionary controls in business operations, and encourage the participation of users in the provision of services.

3. Macroeconomic management is aimed at establishing a stable economic environment through appropriate fiscal, monetary, exchange rate, and sustainable debt policies. However, macroeconomic management started worsen around October 2007 and the risk of debt distress has emerged. Tajikistan's long term prospects remain positive only if the authorities move quickly to restore sound macroeconomic management and implement institutional reforms to improve the business climate, the financial sector, the agricultural sector, transparency and governance of large state-owned enterprises, and public financial management. Expansion in aluminum processing capacity to service continued high world demand, recovery in cotton production following institutional reforms, buoyant inflows of remittances, and the start of a large-scale Russianfinanced hydroelectric power project and other infrastructure investments have the potential to support growth of 7-8 percent over the long term.

4. The IMF has taken the lead in assisting Tajikistan in enhancing macroeconomic stability. The Fund has encouraged the authorities to continue with fiscal consolidation, maintain a restrictive monetary policy, and conduct prudent debt management policy to enhance its sustainability.

5. The World Bank has taken the lead in the policy dialogue on structural issues, including poverty reduction measures, agriculture sector reforms, private sector development, institution building, budget planning, improving public service delivery, and governance. A range of instruments is used to conduct the dialogue. Policy based lending and technical assistance are supporting reforms in a number of sectors. The second Programmatic Development Policy Grant (PDPG) operation of three annual development policy financing 
program to support government's medium-term reform program was approved in July 19, 2007. The program s supporting the government in the areas of public administration reform, public expenditure management, social service delivery, and private sector development.

6. This broad-based approach is combined with sector projects in health, education, municipal infrastructure, power, agriculture, environment, and poverty alleviation. Over the last three years the Bank in collaboration with others has produced analytical work aimed at informing program design. A country procurement assessment report, a country financial accountability assessment, a public and civil service wage note and an update, and a remittances note have informed the public sector reform program. A trade diagnostic, an investment climate assessment, an aviation sector note, an energy utility reform review, the Central Asia Regional Electricity Export Potential Study, and an Agricultural Development Strategy have highlighted key reforms required to attract private sector investment. A poverty assessment update has deepened understanding of poverty and its dynamics, and is important for the design of policy reforms that effectively reduce poverty. Poverty and social impact assessments of cotton and energy reforms have helped promote dialogue with the government on issues of social protection. A programmatic public expenditure review is supporting Tajikistan's first public expenditure and financial accountability review, and analyzing the country's prospects for achieving the MDGs and long-term growth, and providing support for the introduction of the MTEF. Two public expenditure tracking surveys, one for health and one for education, are expected to promote transparency and efficiency of expenditure in these sectors. A country environmental analysis has identified policy and capacity reforms to improve environmental management. 


\section{Tajikistan: Collaboration of the World Bank and the IMF}

\begin{tabular}{|c|c|c|c|}
\hline Area & $\begin{array}{l}\text { Specialized Advice from } \\
\text { Fund }\end{array}$ & $\begin{array}{l}\text { Specialized Advice } \\
\text { from Bank }\end{array}$ & Key Instruments \\
\hline $\begin{array}{l}\text { Economic } \\
\text { Framework/ } \\
\text { Management }\end{array}$ & $\begin{array}{l}\text { Monetary policy, exchange } \\
\text { rate, fiscal, and trade } \\
\text { policies, economic statistics }\end{array}$ & $\begin{array}{l}\text { Economic growth, } \\
\text { economic statistics }\end{array}$ & $\begin{array}{l}I M F \text { : Dialogue on performance } \\
\text { criteria and benchmarks on } \\
\text { monetary and fiscal targets. } \\
\text { Bank: PDPG and Strengthening } \\
\text { National Statistics System Project } \\
\text { under implementation. }\end{array}$ \\
\hline Budget & $\begin{array}{l}\text { Medium-term budget } \\
\text { framework, tax and customs } \\
\text { policy and administration, } \\
\text { and treasury and debt } \\
\text { management }\end{array}$ & $\begin{array}{l}\text { Budget management, } \\
\text { debt management and } \\
\text { statistics, public } \\
\text { expenditure and } \\
\text { financial management } \\
\text { reform }\end{array}$ & $\begin{array}{l}I M F \text { : Dialogue on performance } \\
\text { criteria on overall fiscal balance, } \\
\text { including the public investment } \\
\text { program. Structural benchmark } \\
\text { on treasury development. } \\
\text { Bank: PDPG, Public Sector } \\
\text { Reform Project (PSRP) (under } \\
\text { implementation); TA for public } \\
\text { procurement (under } \\
\text { implementation) and external } \\
\text { audit (recently completed) with } \\
\text { grant funding from the } \\
\text { Institutional Development Fund } \\
\text { (IDF). Public Finance } \\
\text { Management Project (under } \\
\text { preparation). }\end{array}$ \\
\hline $\begin{array}{l}\text { Public Sector } \\
\text { Reform }\end{array}$ & & $\begin{array}{l}\text { Civil service reform, } \\
\text { public sector wage } \\
\text { reform, public } \\
\text { administration reform, } \\
\text { health and education } \\
\text { financing }\end{array}$ & $\begin{array}{l}I M F \text { : Dialogue. } \\
\text { Bank: PDPG and PSRP, } \\
\text { Education Modernization Project, } \\
\text { Community and Basic Health } \\
\text { Project and Education for All } \\
\text { Fast Track Initiative Catalytic } \\
\text { Fund Grant (all under } \\
\text { implementation). }\end{array}$ \\
\hline $\begin{array}{l}\text { Private and } \\
\text { Financial } \\
\text { Sector } \\
\text { Development }\end{array}$ & $\begin{array}{l}\text { Bank supervision; } \\
\text { development of the } \\
\text { interbank market and } \\
\text { increasing competition in } \\
\text { the banking sector. }\end{array}$ & $\begin{array}{l}\text { Investment climate, } \\
\text { developing and } \\
\text { implementing the } \\
\text { private sector } \\
\text { development strategy, } \\
\text { farm privatization, } \\
\text { cotton debt resolution, } \\
\text { land reform, financial } \\
\text { sector reform. }\end{array}$ & $\begin{array}{l}I M F \text { : Dialogue. } \\
\text { Bank: PDPG, Land Cadastre } \\
\text { Project and Cotton Sector } \\
\text { Modernization Project (all under } \\
\text { implementation). } \\
\text { TA for Private Sector } \\
\text { Development Strategy under } \\
\text { implementation with grant } \\
\text { funding from the IDF. A grant } \\
\text { from FIRST financial sector } \\
\text { reform, including reform of NBT, } \\
\text { is under implementation. }\end{array}$ \\
\hline Other Sectors & & Reforms in agriculture, & Bank: PDPG, Education \\
\hline
\end{tabular}




$\begin{array}{ll}\begin{array}{l}\text { energy, health, } \\ \text { education, water and }\end{array} & \text { Modernization, Community and } \\ \text { sanitation, environment, } & \text { Basic Health, Municipal } \\ \text { infrastructure. } & \text { Infrastructure Development, } \\ & \text { Energy Loss Reduction, } \\ & \text { Dushanbe Water Supply, Land } \\ & \text { Cadastre, Ferghana Valley Water, } \\ & \text { Cotton Sector Modernization } \\ & \text { Projects (all under } \\ & \text { implementation). }\end{array}$

\section{B. World Bank Collaboration in Specific Areas}

\section{Areas in which the World Bank leads and there is little direct IMF involvement}

7. Areas in which the Bank leads and there is no direct IMF involvement include the social sectors, infrastructure, and environmental management. In the social sphere, the Bank has carried out regular poverty assessments to monitor poverty and develop programs to alleviate poverty. It has prepared a poverty assessment update has been prepared on the basis of the 2003 living standards survey. Under the Strengthening National Statistics System Project, data collection of a new living standards survey was completed in 2007; analysis of the results is underway.

8. In education, the Bank is providing policy advice and investment resources. The ongoing Education Modernization Project (FY03) aims to upgrade the basic education system by supporting reforms in education financing and management, curriculum and textbooks development; teacher training and student assessment improvement, and upgrading school facilities. Tajikistan has also received grant funding from the Education for All Fast Track Initiative catalytic fund, administered by the Bank. Key issues in education, apart from infrastructure rehabilitation and capacity building, are pay reform, per capita financing and expenditure tracking. Assistance to this sector will continue through the PDPG, a multidonor education investment program, and the PSRP. The Bank is also helping with wage reform in education and a gradual move towards program-based budgeting in the sector through the PDPG. Jointly with the UNICEF the Bank assists the government in the overall national education strategy formulation. The IMF has in the past supported the education reform process, in close collaboration with the World Bank, through a PRGF structural benchmark requiring the drawing up of a fully costed education reform plan by the government.

9. In health, the Bank is helping the government to improve the effectiveness and efficiency of delivery - both of which are aimed at ensuring the poor access to a basic level of services. Through the Community and Basic Health Project and the PDPG, the Bank is helping to strengthen the institutional capability (both at the center and district levels) to carry out health care reforms, to improve the system for budgeting and spending for basic health services, and pay reform. It is also supporting programs to prevent the spread of HIV/AIDS, malaria, and other communicable diseases. The Avian Fluenza Control and Human Pandemic Preparedness and Response is minimizing the threat of highly pathogenic avian influenza infection and other zoonoses posed to humans and poultry; and preparing for 
control and respond to influenza pandemics and other infectious disease emergencies in humans.

10. With regard to infrastructure development, the Bank is concentrating on upgrading basic utility services for the population as a whole and especially the poor. The Dushanbe Water Supply Project is helping the Dushanbe municipality and the local water company to address the most critical deficiencies of water supply services. The Pamir Private Power Project is supporting improvements in reliability of electricity supply in the Gorno Badakshan region with participation of the private sector. The Energy Loss Reduction Project is helping to reduce commercial losses and improve the financial viability of the power and gas sectors. The Bank has also been leading policy dialogue (under PDPG) on increasing efficiency/viability to ensure long-term growth prospects of the energy sector. The Municipal Infrastructure Project is providing support to improve urban infrastructure in big towns.

11. In agriculture, the Bank is concentrating on land reform, rehabilitation of irrigation and drainage infrastructure, and introduction of market rules in procurement of inputs and marketing of outputs as well as on the resolution of the cotton farm debts. The Land Registration and Cadastre Project is assisting the government with the land reform, issuance of land certificates, and establishment of a modern cadastre system. The Ferghana Valley Project aims to increase water supply and efficiency of irrigation systems in the Ferghana Valley, and develop institutional capacity in land and water resources management. The Cotton Sector Recovery Project is helping to improve the livelihoods of cotton farmers and to create conditions for sustainable growth of cotton production in selected, low-income areas. The project is doing this through assistance for cotton debt resolution, for an improved policy environment, and for increased cotton output and profitability. Cross cutting policy issues for increasing productivity in cotton sectors are being addressed through the PDPG.

12. The Bank has supported programs to improve environmental management and to deal with natural disasters. A National Environment Action Plan was developed with the Bank's help. A 2008 Country Environmental Analysis has highlighted the country's most severe environmental issues and proposed measures to strengthen the legal and institutional framework for addressing them. The Emergency Flood Assistance and Lake Sarez Risk Mitigation Projects have helped the government to mitigate the consequences of natural disasters and to build national capacity to address frequent natural hazards such as mudslides, rock-falls, avalanches, and seasonal floods.

\section{Areas in which the World Bank leads and its analysis serves as input into the IMF program}

13. The Bank leads the dialogue on structural reforms through the three-year PDPG program currently under implementation. Institution building and technical assistance in support of PDPG structural reforms come from several sources, including the PSRP, the Education Modernization Project, Fast Track Initiative Grant and the Community and Basic Health Project.

14. The Bank and the Fund both support private sector development, including in the areas of financial transparency and improvements in the regulatory framework. The Bank has 
completed the Investment Climate Assessment and agriculture sector review to determine the most important impediments to private sector development. Tajikistan has participated in three Doing Business surveys and in three Business Environment and Enterprise Performance surveys since the mid-2000s. These provides insight into trends within Tajikistan to improve the business environment and show how Tajikistan is performing relative to other countries of the region. The Bank has supported the preparation of the government's private sector development strategy, which is now under implementation with support of an IDF grant.

15. The Bank and the Fund support enterprise and farm privatization, including acceleration of privatization of medium and large enterprises, improvements to the corporate governance framework for public enterprises, land reform, and restructuring of the cotton subsector. The Bank has completed the Investment Climate Assessment and agriculture sector review to identify obstacles to growth of agricultural productivity. With support of donors, the Bank has been providing technical support to the State Committee for Investments and State Property Management to implement a long-term strategic privatization plan and to promote private sector investment.

16. Regulatory reforms include (a) changing role of anti-monopoly agency and further strengthening its capacity, (b) improving the inspection regime for businesses; and (c) streamlining licensing. In addition, under the PDPG, the Bank is assisting with separating in aviation the functions of policymaking, technical regulation, and accident investigation, with the aim of increasing the transparency and performance of operations. It is also helping with the restructuring the Tajik Air Company aimed at creating separate entities to operate the airport, airline, and air traffic control system. This restructuring is expected to increase the competitiveness of Tajikistan's aviation sector, with benefits for economic growth and poverty reduction.

17. While the Bank has taken the lead in privatization and in structural reforms in the private sector, the IMF has also a strong interest in these areas, since many of these reforms are critical to achieving macroeconomic stabilization and enhancing growth. Accordingly, the two institutions maintain an active dialogue with each other on these matters to ensure good coordination of interventions.

\section{Areas of shared responsibility}

18. The Bank and the Fund are working jointly in the following four main areas (supported by the Bank's PDPG, grants, and several investment operations, and the Fund's SMP):

- Public sector management. The Bank has provided technical support to the government to develop a comprehensive public administration reform strategy. It includes policy actions in public administration reforms aimed at redefining the role of the state in line with the market economy needs, reorganizing key ministries, strengthening the internal control and audit function, and supporting the pay reform. The Bank is involved in civil service reform while the Fund is providing technical assistance in support of tax and customs administration and treasury management. 
- Budget planning and execution. Both institutions work on providing support for a treasury, adoption of new law on public finances introducing modern budgetary procedures and improved fiscal management, and switching from norm-based costing and allocation of expenditures to per capita based financing in education and health sectors. The Bank will continue to provide technical support and mobilize donor funds to implement the medium-term budget framework. The Bank will also continue to support public financial external and internal control reform through the PDPG, IDF grants, and the PSRP. The forthcoming Public Financial Management Project (FY09) will support treasury reform.

- Financial sector reforms. This area includes the acceleration of financial sector restructuring and closure of weak banks, a new regulatory framework for the establishment of non-bank intermediaries, and significant changes in the tax code making tax authorities' access to bank accounts conditional on a court authorization. In terms of banking supervision, the IMF is monitoring the closure and merger of banks that do not satisfy prudential requirements. A Financial Sector Assessment Program (the country's first), carried out jointly by the Bank and the Fund, was discussed with the authorities in late 2007. The Bank is implementing a grant from the FIRST trust fund to support implementation of the assessment's recommendations, especially needed reforms at the NBT.

- Utilities reform. The Fund included in its former PRGF benchmarks related to energy tariff rates, energy arrears, and collection rates with the aim to reduce quasifiscal activities and increase transparency. The Bank under the PDPG is supporting tariff reform aimed at reducing the quasi-fiscal deficit. It also supported the conducting of an audit of Barki Tajik's accounts, which was completed in August 2008. The Bank is providing financial assistance to help the government to repair the electricity and gas transmission system, to import the energy needed to meet periodic winter shortfalls, and to help implement the Energy Emergency Action Mitigation Plan. The Bank-supported Energy Loss Reduction Project is supporting implementation of reforms. The Bank is working closely together with the Asian Development Bank and the EBRD on utilities reform and restructuring of strategic enterprises such as the railways and airlines.

- Debt sustainability analysis: The Bank and the IMF have started carrying out joint debt sustainability analyses (DSA). The first one was done in early 2006 and an update was completed in February 2007. The next joint DSA update will be finalized before February 2009.

\section{Areas in which the IMF leads and its analysis serves as input into the World Bank program}

19. The Fund leads the dialogue on fiscal matters, setting the overall envelope for public expenditures. The Bank's work in key sectors, such as health, education and infrastructure, necessitates close cooperation.

20. In the budgetary area, the Fund is taking the lead on tax reforms and budget preparation and execution. The IMF also leads the dialogue on polices to rationalize and 
contain expenditures in the public sector. These include policies regarding wage setting in both the public service, and defining the ceiling for public investment expenditures. In these areas, the Bank takes into account the policy recommendations of the IMF and ensures that its own policy advice is consistent.

\section{Areas in which the IMF leads and there is no direct World Bank involvement}

21. The Fund takes the lead in the formulation and execution of fiscal and monetary policies, tax policy, external trade policies, and issues involving economic and financial statistics. The Bank-financed Strengthening National Statistics System Project is improving Tajikistan's capacity to collect, analyze, and disseminate key information required for evidence-based decision-making.

\section{IDA Funding}

22. IDA funding to Tajikistan was provided in the form of 100 percent grant in FY06 and FY08; while in FY07 allocation was set with a 45 percent grant component. Tajikistan's eligibility for grants is determined based on the annual debt sustainability analyses. The indicative IDA 15 envelope for FY08-10 is about SDR61.0 million. Of this, about SDR 19.5 million is scheduled for the FY09, about SDR 20.5 million is planned for FY10, around SDR 21.0 million is targeted for FY11. FY09 IDA allocation will be 100 percent grant. 


\section{Annex III. Tajikistan: Relations With The Asian DeVelopment Bank}

(As of November 21, 2008)

Country Director: Mr. Makoto Ojiro-Telephone: 992-372-210558/235314/235315

1. Tajikistan became a member of the Asian Development Bank (ADB) in 1998. The ADB has participated in the Consultative Group Meeting for Tajikistan since 1998. After conducting an initial mission in June 1998, ADB completed an Economic Report and Interim Operational Strategy that identified three areas: (a) agriculture; (b) infrastructure rehabilitation (especially energy and transport sectors); and (c) social sector, in which ADB assistance would have the greatest development impact. Based on the Interim Strategy, ADB's Board of Directors approved in October 1998 Tajikistan's country classification, which provides the basis for Tajikistan's full access to concessional resources (Asian Development Fund (ADF)). Under the new ADF grants framework, Tajikistan receives 50\% of its ADF allocation as loan and the remaining 50\% as grant, subject to a $20 \%$ volume discount. Under the performance-based allocation of ADF for 2007-2008, Tajikistan was allocated $\$ 63.24$ million for the two-year period. As of end 2007, Tajikistan has received $\$ 372.50$ million in loans, \$33.00 million in technical assistance, and \$39.50 million in grants.

2. In view of Tajikistan's urgent need for assistance in 1998, in coordination with the IMF and the World Bank (WB), the ADB provided a Postconflict Infrastructure Program Loan (\$20 million), which was designed to create a framework for developing market-based transport and energy sectors. The loan was for two years and was fully disbursed by end2000. Based on the satisfactory progress of the Postconflict Infrastructure Program loan conditionality, the following loans were approved in these two sectors:

3. Transport Sector: the Road Rehabilitation Project loan (\$20 million in 2000), which rehabilitated the most deteriorated sections of the Dushanbe-Kulyab road in the southern part of Tajikistan, the most civil-war affected areas; Dushanbe-Kyrgyz Border Road Rehabilitation Project loans (first phase of \$15 million in 2003 and second phase of \$30 million in 2005); and the Regional Road Corridor Improvement Project (\$53.4 million loan/grant in 2007), which improve Tajikistan's transportation link toward north and east through Kyrgyz Republic, further to Kazakhstan and Russia, as well as to the People's Republic of China. These projects also improve rural roads in the project areas. Continued supports in strengthening the government's institutional capacity for efficient management of national road network are provided under technical assistance grants associated with these loans and provided on stand-alone basis. In October 2007, ADB approved a \$2.0 million Japan Fund for Poverty Reduction grant to reconstruct key infrastructure in northeast Tajikistan to restore access to rural communities that were isolated after flooding in 2006 washed away a suspension bridge.

4. Power Sector: the Power Rehabilitation Project loan (\$34 million in 2000) aims to improve people's quality of life and support poverty reduction by increasing the availability of electricity, and assist in post-conflict recovery of Tajikistan's economy (the project 
rehabilitates and reinforces power transmission and distribution facilities in the war-damaged areas in Khatlon and Dushanbe regions, and rehabilitates the Nurek Power Plant and Central Hydropower Plant). The Regional Power Transmission Modernization Project loan (\$20 million in 2002) was geared towards improving the reliability and the operation of the Central Asian power transmission system, enhancing the intercountry power trading between Tajikistan and Uzbekistan, and laying the foundation for a future wholesale regional power market. However, the later loan had to be cancelled due to the inability of Tajikistan and Uzbekistan agreeing on the Power Trade Agreement. The Tajikistan-Afghanistan Power Transmission Interconnection Project loan for \$21.5 million to Tajikistan was approved in 2006. This project will construct a 220 kilovolt double circuit transmission line that will link the hydropower stations on Tajikistan's Vakhsh River to the border town of Sherkan Bandar, then to Kunduz, Baglad, Pul-e-Khumri and, ultimately, Kabul in Afghanistan. Various technical assistance projects were provided to accelerate market-oriented reforms in the power sector also in line with IMF and WB programs and for supporting the government in formulating a power sector development strategy. ADB is also providing a technical assistance to support the techno-economic assessment for the establishment of a Central Asia South Asia Regional Electricity Market (CASAREM) for electricity trading between Afghanistan, Kyrgyz Republic, Pakistan, and Tajikistan.

5. In addition to the above, the ADB Board approved to date the following loans to Tajikistan in each sector:

6. Social Sector: the Social Sector Rehabilitation Project loan (\$20 million in 1999) to address the serious deterioration in living standards and strengthen the delivery of essential social services; the Health Sector Reform Project loan (\$7.5 million in 2003), which aims to improve health, especially of the poor, women, and children by providing pro-poor health service package, and by reforming the health service delivery and financing mechanism; and the Education Sector Reform Project loan (\$7.5 million in 2003), which focuses on supporting the government's reform priorities in primary (grades 1-4) and general secondary education (grades 5-11) by improving the education system and its management. These two social sector reform loans are being supported by respective grants financed by Japan Fund for Poverty Reduction (JFPR): (a) the project for Community Participation and Public Information Campaign for Health Improvement (\$1 million in 2004); and (b) the School Improvement Project ( $\$ 2$ million in 2004), which aims to increase access to improved education for children, particularly girls, of poor families and vulnerable groups.

7. Agriculture Sector: based on the agriculture sector assessment prepared during 1999-2000, the Agriculture Rehabilitation Project loan (\$35 million in 2002) is being implemented to improve living conditions of the farming communities in the project area and to institute measures to sustain benefits of improvements for irrigation and drainage systems and water supply, as well as by providing farm production support services. In order to support the agriculture sector reforms, the TA for Farm Debt Resolution and Policy Reforms, which was associated with the loan, has been completed in consultation with the IMF, involving a wide range of stakeholders. Based on the findings of the TA, ADB supported the 
government in close cooperation with other donors and NGOs for formulating a National Farm Debt Resolution Strategy. A wide range of donor assistance is now needed as the Strategy has been announced by the government. ADB, in collaboration with DFID, is supporting donor coordination for implementing the Strategy. On 5 March 2007, the Government approved the Roadmap for Implementation of the Farm Debt Resolution Strategy. The road map, which includes a comprehensive program of reforms for the sustainable and profitable farming of cotton and other crops, guides the preparation of a suitable intervention for ADB. Grant assistance for Rural Poverty Reduction Project (\$2.9 million in 2001) financed by JFPR has supported the loan preparation and implementation by pilot testing innovative poverty-oriented on- and off-farm supports. In 2004, Irrigation Rehabilitation Project loan was approved for \$22.7 million. In a major push supporting the agriculture sector and rural development, Sustainable Cotton Sub-Sector Project loan/grant and Rural Development Project loan/grant were approved in 2006 and 2007, respectively.

8. Finance: Microfinance Systems Development Program loan (\$4 million in 2003) to support policy, legal, and regulatory reforms; and Microfinance Systems Development Project loan (\$4 million in 2003) to help transform nongovernmental organization microfinance programs into licensed and regulated microfinance institutions.

9. Trade Facilitation: the Regional Trade Facilitation and Customs Cooperation Program loan (\$10 million in 2002), which supported trade and customs reform development across the East and Central Asia. Regional Customs Modernization and Infrastructure Development ( $\$ 10.7$ million in 2004) to promote international trade and enabling environment for private sector development.

10. Emergency Assistance: in response to the government's urgent requests, three emergency loans, including the Emergency Flood Rehabilitation Project loan (\$5 million in 1999), the Emergency Restoration of Yavan Water Conveyance System loan (\$3.6 million in 2001), and the Emergency Baipaza Landslide Stabilization Project loan (\$5.3 million in 2002) were approved. In 2007, ADB provided a $\$ 22$ million loan for the Khatlon Province Flood Risk Management Project to help address recurring flood risks in four districts in the province through a comprehensive and coordinated approach. A major part of the project is the rehabilitation of 8.3 kilometers of flood protection embankment along Pyanj River, which borders Tajikistan and neighboring Afghanistan.

11. In end-2000, ADB started supporting the government in developing PRSP through participatory approach under a TA grant in close cooperation with the IMF, WB, and UNDP. Following the finalization of the PRSP in June 2002, ADB concluded the Poverty Partnership Agreement (PPA) with the government in December 2002, and proceeded to prepare a new five-year Country Strategy and Program (CSP) for 2004-08 for Tajikistan, which was endorsed by the ADB Board in October 2003. Its main objectives are (a) to strengthen rural development through institution building that will support policy implementation and the private sector; (b) to rehabilitate power and rural infrastructure; and (c) to strengthen regional 
cooperation through improved customs services and transport links, both within the country and neighboring ones.

12. ADB prepares and updates its three-year rolling programs for Tajikistan every year in consultation with the government based on the ADF resources availability, carefully examining the country's social and economic development status and in coordination with other donors, including IMF. The latest Country Operations Business Plan for Tajikistan covering 2008-2010 was approved in October 2007. Currently, a joint country support strategy for Tajikistan for 2009-2012 is being developed with the joint support of ADB, European Commission, Swiss Development Corporation, UK Department for International Development, United Nations, and World Bank. The strategy is planned for finalization by the end of 2008 and expected to be managed through a result-based framework. ADB pays full attention to the progress of Tajikistan's MDG achievement. ADB is also paying intensive attention to governance reforms through investment projects and technical assistance. In 2006, ADB approved a technical assistance project entitled Strengthening Results Management in Support of Poverty Reduction in Tajikistan cofinanced by the Swedish Government. The \$2.0 million grant package co-financed by the Government of the United Kingdom's Department for International Development was approved in 2007 to help boost the Tajikistan government's capacity in promoting private sector development.

13. The proposed 2008-2010 lending and grant program comprises three programs and three projects worth a total of $\$ 185.0$ million. The actual lending level will be determined by (a) availability of overall ADF resources; (b) country performance assessment vis-à-vis ADB's policy on performance based allocation of ADF resources; and (c) processing status of the projects in the pipeline. 


\section{ANNEX IV. TAJIKISTAN: STATISTICAL ISSUES}

1. Data provision has some shortcomings, but is broadly adequate for surveillance. After a serious misreporting episode, Tajikistan data reporting to the Fund has begun to improve.

2. Tajikistan began participation in the Fund's General Data Dissemination System (GDDS) in November 2004 and the country page in the International Financial Statistics (IFS) has been published since February 2003. The authorities have indicated their interest in graduating from the GDDS to the Fund's Special Data Dissemination Standard (SDDS). They have appointed a national SDDS coordinator and requested technical assistance for this purpose. Before subscribing to the SDDS, Tajikistan will need to compile and disseminate the following datasets: quarterly national accounts, template on international reserves and foreign currency liquidity, and international investment position. Also, Tajikistan will need to disseminate regularly general government operations that include special funds (extrabudgetary accounts) at least on an annual basis, quarterly central government debt, and quarterly external debt data, with improved timeliness for several data categories.

3. The data ROSC mission in April 2004 found that government finance statistics (GFS), and monetary statistics broadly follow sound methodologies. The mission also noted that source data are well-developed in all areas of statistics, and that suitable processes for assessment and validation of source data are in place. However, further efforts to improve the quality of economic statistics are limited by tight budgetary constraints.

\section{National Accounts and Price Statistics}

4. The ROSC mission identified significant deficiencies in statistical techniques for national accounts and price statistics, most notably in procedures to estimate the informal economy, and in the techniques for imputation, replacement, quality adjustment, and introduction of new products in the price indices. The State Committee on Statistics (SCS) has benefited from technical assistance under the World Bank STATCAP project and through an arrangement with a consortium of five European Statistical Offices. This has led to improved GDP estimates for 2000 to 2006, though a May 2008 mission by an IMF regional advisor worked with the authorities on problems with the volume estimates. An August 2008 mission by the advisor on their price indices pointed to aggregation and other problems with their CPI.

\section{Government Finance Statistics}

5. Government finance statistics are based on cash transactions as recommended in $A$ Manual on Government Finance Statistics, 1986. Although there are no plans at present to migrate the basis of compilation to the Government Finance Statistics Manual 2001, the cash GFS operations data were reported in the new framework for inclusion in the $2005 \mathrm{GFS}$ Yearbook. No details on financing of the cash deficit were reported. Data with a higher frequency for inclusion in the IFS are not reported. 


\section{Monetary and Financial Statistics}

6. A monetary and financial statistics (MFS) mission visited Tajikistan in early 2006 and assisted the authorities in establishing the procedures for compiling analytical accounts for commercial banks using data collected from the revised chart of accounts. The mission also assisted the authorities in implementing the Standardized Report Forms (SRFs) for MFS developed by STA. The authorities resumed regular reporting of monthly monetary data to STA for publication in IFS shortly after the mission. Further efforts are needed to implement the SRFs and the mission's other recommendations for improving the collection, compilation, and dissemination of MFS. However, due to the recent misreporting episode, the authorities stopped reporting monetary data to STA for publication in IFS in December 2007. The reporting was resumed in September 2008. The reported data on monetary authorities were published in November 2008 issue of IFS and data on deposit money banks will be published in the January 2009 issue of IFS.

\section{Balance of Payments Statistics}

7. There is a need for consistency in applying the residency concept in the balance of payments and the national accounts, and the scope of the foreign trade data needs to be improved to cover the shuttle trade. 


\section{TAJIKISTAN: TABLE OF COMMON INDICATORS REQUIRED FOR SURVEILLANCE}

\section{(As of December 1, 2008)}

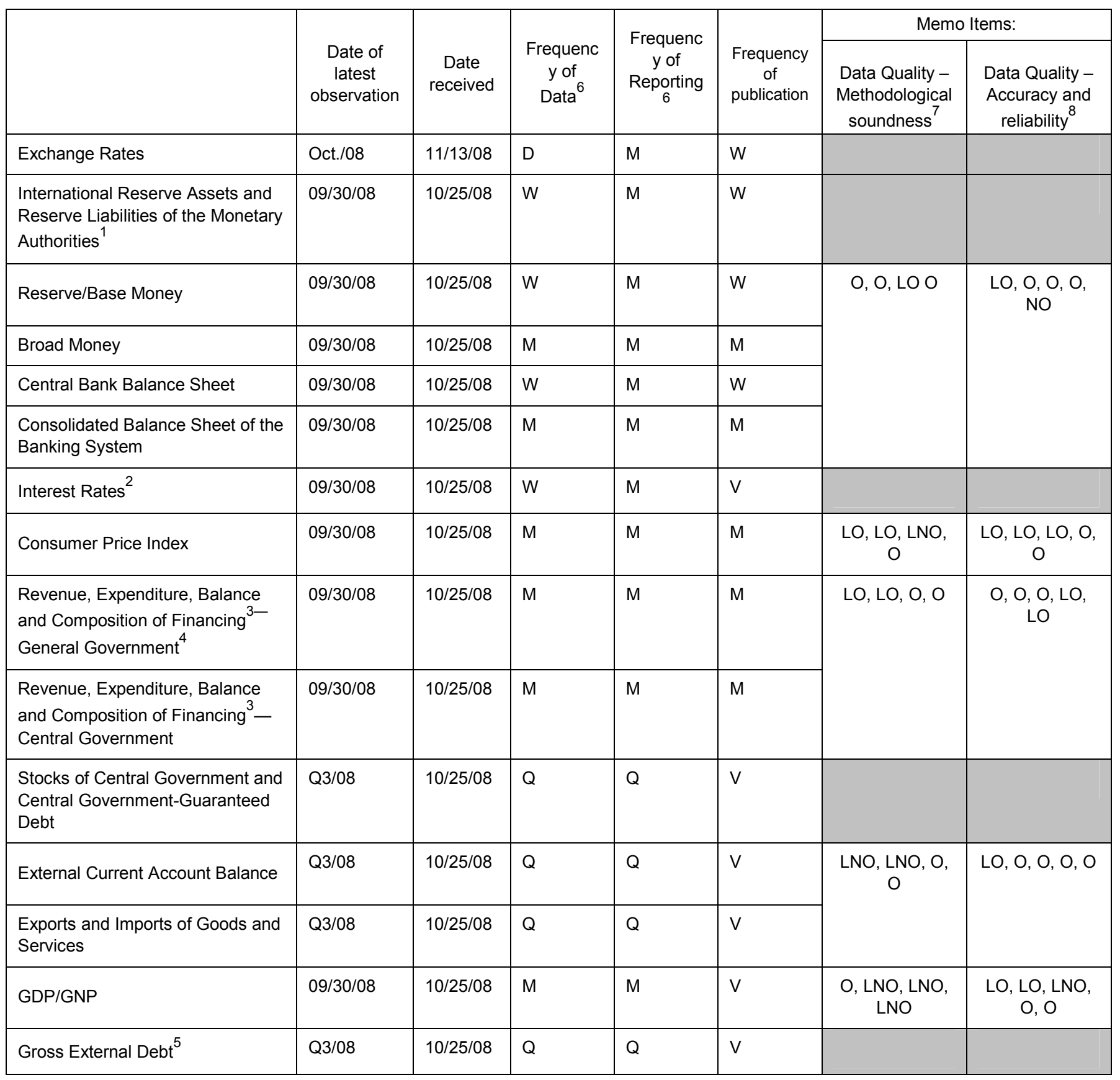

${ }^{1}$ Includes reserve assets pledged or otherwise encumbered, as well as net derivative positions.

${ }^{2}$ Both market-based and officially determined, including discount rates, money market rates, and rates on treasury bills, notes and bonds.

${ }^{3}$ Foreign, domestic bank, and domestic nonbank financing.

${ }^{4}$ The general government comprises central government (budgetary, extra budgetary, and social protection funds) and state and local governments.

${ }^{5}$ Including currency and maturity composition.

${ }^{6}$ Daily (D), Weekly (W), Monthly (M), Quarterly (Q), Annually (A); NA: Not Available.

${ }^{7}$ Reflects the assessment provided in the data ROSC published in April 2005 and based on the findings of the staff mission during April 2004 for the dataset corresponding to the variable in each row. The assessment indicates whether international standards concerning concepts and definitions, scope, classification/sectorization, and basis for recording are fully observed (O), largely observed (LO), largely not observed (LNO), or not observed (NO).

${ }^{8}$ Same as footnote 7, except referring to international standards concerning source data, statistical techniques, assessment and validation of source data, assessment and validation of intermediate data and statistical outputs, and revision studies. 